\title{
Changes to the chemical state of the Northern Hemisphere atmosphere during the second half of the twentieth century
}

\author{
Mike J. Newland ${ }^{1}$, Patricia Martinerie ${ }^{2, a}$, Emmanuel Witrant ${ }^{3}$, Detlev Helmig ${ }^{4}$, David R. Worton ${ }^{5}$, Chris Hogan ${ }^{1}$, \\ William T. Sturges ${ }^{1}$, and Claire E. Reeves ${ }^{1}$ \\ ${ }^{1}$ Centre for Ocean and Atmospheric Sciences, School of Environmental Sciences, University of East Anglia, Norwich, UK \\ ${ }^{2}$ Univ. Grenoble Alpes/CNRS, LGGE, 38000 Grenoble, France \\ ${ }^{3}$ Univ. Grenoble Alpes/CNRS, GIPSA-Lab, 38000 Grenoble, France \\ ${ }^{4}$ Institute of Arctic and Alpine Research, University of Colorado, Boulder, Colorado, USA \\ ${ }^{5}$ National Physical Laboratory, Teddington, Middlesex, UK \\ ${ }^{a}$ now at: Wolfson Atmospheric Chemistry Laboratories, Department of Chemistry, University of York, York, UK
}

Correspondence to: Mike J. Newland (mike.newland@york.ac.uk)

Received: 14 October 2016 - Discussion started: 30 November 2016

Revised: 1 May 2017 - Accepted: 18 May 2017 - Published: 7 July 2017

\begin{abstract}
The $\mathrm{NO}_{x}\left(\mathrm{NO}\right.$ and $\left.\mathrm{NO}_{2}\right)$ and $\mathrm{HO}_{x}\left(\mathrm{OH}\right.$ and $\left.\mathrm{HO}_{2}\right)$ budgets of the atmosphere exert a major influence on atmospheric composition, controlling removal of primary pollutants and formation of a wide range of secondary products, including ozone, that can influence human health and climate. However, there remain large uncertainties in the changes to these budgets over recent decades. Due to their short atmospheric lifetimes, $\mathrm{NO}_{x}$ and $\mathrm{HO}_{x}$ are highly variable in space and time, and so the measurements of these species are of limited value for examining long-term, largescale changes to their budgets. Here, we take an alternative approach by examining long-term atmospheric trends of alkyl nitrates, the production efficiency of which is dependent on the atmospheric $[\mathrm{NO}] /\left[\mathrm{HO}_{2}\right]$ ratio. We derive long-term trends in the alkyl nitrates from measurements in firn air from the NEEM site, Greenland. Their mixing ratios increased by a factor of 3-5 between the 1970s and 1990s. This was followed by a steep decline to the sampling date of 2008. Moreover, we examine how the trends in the alkyl nitrates compare to similarly derived trends in their parent alkanes (i.e. the alkanes which, when oxidised in the presence of $\mathrm{NO}_{x}$, lead to the formation of the alkyl nitrates). The ratios of the alkyl nitrates to their parent alkanes increased from around 1970 to the late 1990s. This is consistent with large changes to the $[\mathrm{NO}] /\left[\mathrm{HO}_{2}\right]$ ratio in the Northern Hemisphere atmosphere during this period. Alternatively, they could represent changes to concentrations of the hydroxyl radical, $\mathrm{OH}$, or to the transport time of the air masses from source regions to the Arctic.
\end{abstract}

\section{Introduction}

The $\mathrm{NO}_{x}\left(\mathrm{NO}+\mathrm{NO}_{2}\right)$ and $\mathrm{HO}_{x}\left(\mathrm{OH}+\mathrm{HO}_{2}\right)$ budgets of the troposphere act to control the concentrations of oxidants such as $\mathrm{OH}$, ozone and $\mathrm{NO}_{3}$ (Fig. 1). These in turn control removal of pollutants from the atmosphere. Emissions of $\mathrm{NO}_{x}$ in the Northern Hemisphere are mainly anthropogenic, with roughly equal proportions from power generation and transport (Olivier and Berdowski et al., 2001; Olivier et al., 2001). $\mathrm{NO}_{x}$ and $\mathrm{HO}_{x}$ are linked through ozone production, which is positively correlated with $\mathrm{NO}_{x}$ concentrations in the background atmosphere through the photolysis of $\mathrm{NO}_{2}$ (Reactions R1-R2). The photolysis of ozone in the presence of water vapour then leads to the production of OH (Reactions R3R4). Other processes, such as alkene ozonolysis (Johnson and Marston, 2008) and photolysis of HONO (formed from heterogeneous reactions of $\mathrm{NO}_{2}$, Stone et al., 2012) may also be important primary sources of $\mathrm{HO}_{x}$, particularly in winter (e.g. Heard et al., 2004).

Removal of $\mathrm{NO}_{x}$ from the atmosphere is controlled by the reaction of $\mathrm{NO}_{2}$ with $\mathrm{OH}$ during the daytime (Reaction $\mathrm{R} 5$ ). This forms nitric acid, $\mathrm{HNO}_{3}$, which is lost from the atmosphere by wet deposition. At night and during the winter, the heterogeneous reaction of the $\mathrm{NO}_{x}$ reservoir species $\mathrm{N}_{2} \mathrm{O}_{5}$, formed from the reaction of $\mathrm{NO}_{2}$ with $\mathrm{NO}_{3}$ (Reactions R6R7), with $\mathrm{H}_{2} \mathrm{O}$ on aerosol becomes an important $\mathrm{NO}_{x}$ sink (Reaction $\mathrm{R} 8$ ). $\mathrm{OH}$ and $\mathrm{HO}_{2}$ rapidly interconvert through the reactions of $\mathrm{OH}$ with $\mathrm{CO}$ and hydrocarbons, such as alkanes, and the reaction of $\mathrm{HO}_{2}$ with $\mathrm{NO}$ (Reaction R9). The 


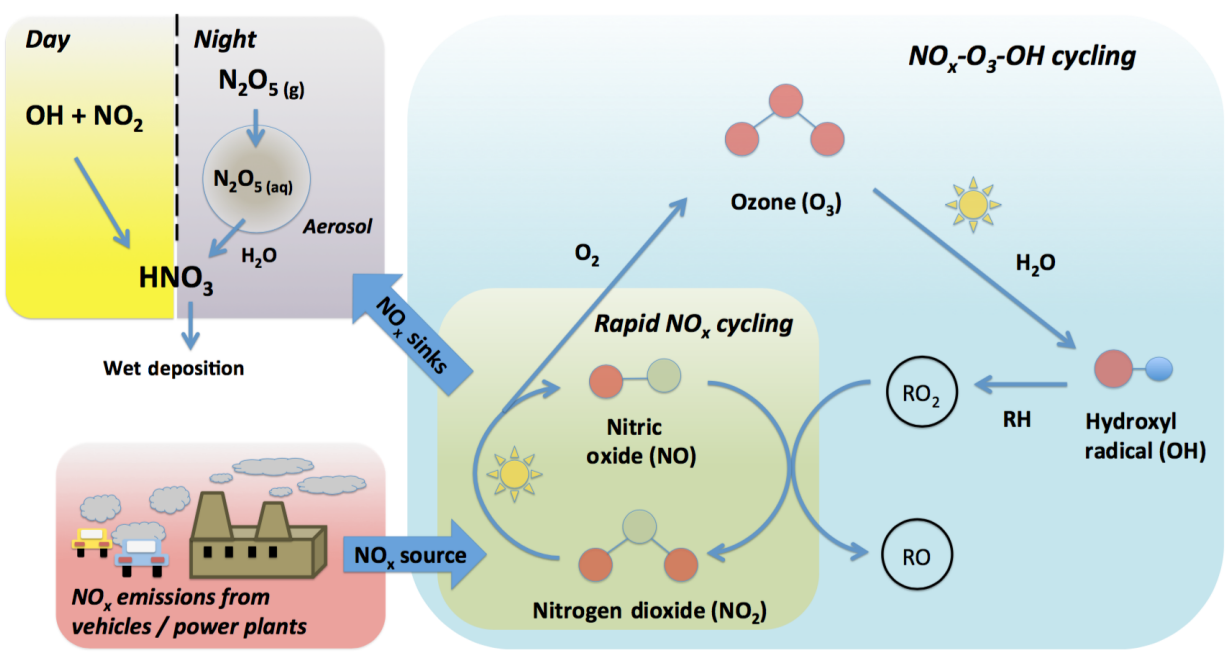

Figure 1. Schematic of the $\mathrm{NO}_{x}-\mathrm{O}_{3}-\mathrm{OH}$ relationship in the background troposphere.

reaction of $\mathrm{NO}$ with peroxy radicals $\left(\mathrm{HO}_{2}\right.$ and $\mathrm{RO}_{2}-$ Reactions $\mathrm{R} 9-\mathrm{R} 10$ ) recycles the $\mathrm{NO}$ back to $\mathrm{NO}_{2}$. The main removal process for $\mathrm{HO}_{x}$ in urban regions is the reaction of $\mathrm{OH}$ with $\mathrm{NO}_{2}$ (Reaction R5) (Stone et al., 2012), while $\mathrm{HO}_{2}$ selfreaction and reaction with $\mathrm{RO}_{2}$ (in particular $\mathrm{CH}_{3} \mathrm{O}_{2}$ ) (Reactions R11-R12) dominate in low $\mathrm{NO}_{x}$ environments (Stone et al., 2012).

$\mathrm{HO}_{x}$ sources:

$$
\begin{aligned}
& \mathrm{NO}_{2} \stackrel{h v}{\longrightarrow} \mathrm{NO}+\mathrm{O} \\
& \mathrm{O}+\mathrm{O}_{2}+M \rightarrow \mathrm{O}_{3}+M \\
& \mathrm{O}_{3} \stackrel{h v}{\longrightarrow} \mathrm{O}\left({ }^{1} \mathrm{D}\right)+\mathrm{O}_{2} \\
& \mathrm{O}\left({ }^{1} \mathrm{D}\right)+\mathrm{H}_{2} \mathrm{O} \longrightarrow 2 \mathrm{OH}
\end{aligned}
$$

$\mathrm{NO}_{x}$ sinks

$$
\begin{array}{ll}
\text { Day: } & \mathrm{NO}_{2}+\mathrm{OH} \longrightarrow \mathrm{HNO}_{3} \\
\text { Night: } & \mathrm{NO}_{2}+\mathrm{O}_{3} \longrightarrow \mathrm{NO}_{3}+\mathrm{O}_{2} \\
& \mathrm{NO}_{2}+\mathrm{NO}_{3} \leftrightharpoons \mathrm{N}_{2} \mathrm{O}_{5} \\
& \mathrm{~N}_{2} \mathrm{O}_{5}+\mathrm{H}_{2} \mathrm{O} \stackrel{\text { het. }}{\longrightarrow} 2 \mathrm{HNO}_{3}
\end{array}
$$

$\mathrm{NO}_{x}$ and $\mathrm{HO}_{x}$ recycling

$$
\begin{aligned}
& \mathrm{NO}+\mathrm{HO}_{2} \longrightarrow \mathrm{OH}+\mathrm{NO}_{2} \\
& \mathrm{NO}+\mathrm{RO}_{2} \longrightarrow \mathrm{RO}+\mathrm{NO}_{2}
\end{aligned}
$$

$\mathrm{HO}_{x}$ sinks

$$
\begin{aligned}
& \mathrm{HO}_{2}+\mathrm{RO}_{2} \longrightarrow \mathrm{ROOH} \\
& \mathrm{HO}_{2}+\mathrm{HO}_{2} \longrightarrow \mathrm{H}_{2} \mathrm{O}_{2}+\mathrm{O}_{2}
\end{aligned}
$$

However, changes to the atmospheric concentrations of both $\mathrm{HO}_{x}$ and $\mathrm{NO}_{x}$ during the previous century are poorly constrained. This is because all $\mathrm{HO}_{x}$ and $\mathrm{NO}_{x}$ species are short-lived, present at low concentrations (0.01-10 ppt), and have a high spatial and temporal variability (e.g. Stone et al., 2012). This makes them difficult to measure and trends are difficult to identify (based on spatially and temporally variable data sets). Furthermore, a range of state-of-the-art atmospheric chemistry transport models give no consensus of even the sign of $\mathrm{OH}$ change between 1850 and 2000 (Naik et al., 2013). However, the models do agree that between 1980 and 2000 there was an increase in Northern Hemisphere $\mathrm{OH}$ concentrations, with the best estimate of the increase being $4.6( \pm 1.9) \%$. This modelled increase is driven by increases in the $\mathrm{NO}_{x}$ burden and in the water vapour concentration.

To attempt to study historical trends in $\mathrm{HO}_{x}$ and $\mathrm{NO}_{x}$ we have examined trends in longer lived species which are affected by changes to $\mathrm{HO}_{x}$ and $\mathrm{NO}_{x}$ in the atmosphere.

In this paper we report long-term atmospheric trends of three alkyl nitrates (2-butyl nitrate, 2+3-pentyl nitrate, 3methyl-2-butyl nitrate) derived from Arctic firn air. These are chemically produced in the atmosphere from the oxidation of alkanes and subsequent reaction of the peroxy radical formed with NO. The alkyl nitrate records are combined with previously reported trends of their parent alkanes from the same Arctic firn site. These records provide a proxy from which we can learn about the chemical state of the atmosphere at the time they were formed.

\subsection{Alkanes}

Emissions of butanes $\left(\mathrm{C}_{4} \mathrm{H}_{10}\right)$ and pentanes $\left(\mathrm{C}_{5} \mathrm{H}_{12}\right)$ to the atmosphere are almost entirely anthropogenic ( $>98 \%$ globally, Pozzer et al., 2010) and associated with fugitive emissions during oil and natural gas extraction and transmission, and evaporation and combustion of fossil fuels, such as in road vehicles (Pozzer et al., 2010; Pétron et al., 2012; Helmig et al., 2014a). Butane and pentane emissions from vehicles will be dependent on fuel composition, with evapo- 
rative emissions also dependent on temperature. Many areas in North America are part of "ozone attainment areas", and during summer months (June-15 September) they have been required by law since 1990 to provide a gasoline blend with a low Reid vapour pressure (RVP) to reduce the ozone production potential (www.epa.gov). This reduction in RVP is generally achieved by reducing the fuel's butane content relative to wintertime fuel (e.g. Gentner et al., 2009).

Measurements in firn air from Greenland (Aydin et al., 2011; Worton et al., 2012; Helmig et al., 2014b) suggest Northern Hemisphere C2-C5 alkane mixing ratios increased through the middle of the past century to a peak in $\sim 1980$ ( $\sim 1970$ for ethane) and then declined to roughly 1960 levels by 2000. In situ measurements from the urban areas of London (1993-2008) (Dollard et al., 2007; von Schneidemesser et al., 2010) and Los Angeles (1960-2010) (Warneke et al., 2012) show steadily decreasing alkane mixing ratios, as do measurements at the semi-rural site of Hohenpeissenberg, Germany (von Schneidemesser et al., 2010). Emission estimates from the ACCMIP global emission inventory (Lamarque et al., 2010) (available at http://eccad.sedoo.fr) show butane and pentane emissions in Europe and North America increasing steadily between 1950 and 1980 before falling again to roughly 1965 levels by 2000 .

The primary removal mechanism of alkanes from the atmosphere is reaction with the hydroxyl radical, $\mathrm{OH}$ (minor sinks include reaction with atomic chlorine, $\mathrm{Cl}$, and the nitrate radical, $\mathrm{NO}_{3}$ ).

Atmospheric mixing ratios of butanes and pentanes display a large seasonal cycle in mid-high latitudes (e.g. Swanson et al., 2003; Helmig et al., 2009) due to changes in their chemical lifetimes ( $\sim 1$ month in the winter and 4-5 days in the summer) driven by the seasonal cycle in $\mathrm{OH}$ concentration.

\subsection{Alkyl nitrates}

Alkyl nitrates $\left(\mathrm{RONO}_{2}\right)$ are secondary oxidation products of alkanes (RH). Their atmospheric lifetimes are of the order of months in winter and 10 days in summer (Clemitshaw et al., 1997). Consequently, they display a strong seasonal cycle in the Arctic, with peaks in the late winter/early spring and minima in the summer (Swanson et al., 2003), similar to the alkanes. Alkyl nitrates are formed when alkanes react with $\mathrm{OH}$ to form a peroxy radical, $\mathrm{RO}_{2}$ (Reaction $\mathrm{R} 13$ ), which subsequently reacts with NO to form an alkyl nitrate (Reaction 14b) (e.g. Talukdar et al., 1997). This is a minor channel of the $\mathrm{RO}_{2}+\mathrm{NO}$ reaction (Reaction $\mathrm{R} 14 \mathrm{a}$ ) which generally leads to ozone production via recycling of $\mathrm{NO}$ to $\mathrm{NO}_{2}$ and the subsequent photolysis of $\mathrm{NO}_{2}$. $\mathrm{RO}_{2}$ can also react with $\mathrm{HO}_{2}$ (the hydroperoxyl radical) (Reaction R11) to form a peroxide $(\mathrm{ROOH})$. The probability of $\mathrm{RO}_{2}$ reacting with $\mathrm{NO}$ (leading to alkyl nitrate production) is thus governed by the ratio $[\mathrm{NO}] /\left[\mathrm{HO}_{2}\right]$. Alkyl nitrates are lost from the atmosphere by reaction with $\mathrm{OH}$ (Reaction R15), photolysis (Reaction R16) and wet/dry deposition.

$$
\begin{aligned}
& \mathrm{RH}+\mathrm{OH} \stackrel{\mathrm{O}_{2}}{\longrightarrow} \mathrm{RO}_{2}+\mathrm{H}_{2} \mathrm{O} \quad k_{13}, \alpha_{13} \\
& \mathrm{RO}_{2}+\mathrm{NO} \longrightarrow \mathrm{RO}+\mathrm{NO}_{2} \quad k_{14},\left(1-\alpha_{14}\right) \\
& \longrightarrow \mathrm{RONO}_{2} \\
& k_{14} \alpha_{14} \\
& \mathrm{RO}_{2}+\mathrm{HO}_{2} \longrightarrow \mathrm{ROOH} \quad k_{11} \\
& \mathrm{RONO}_{2}+\mathrm{OH} \longrightarrow \text { products } \quad k_{15} \\
& \mathrm{RONO}_{2} \stackrel{h v}{\longrightarrow} \text { products } \quad j_{16}
\end{aligned}
$$

\section{Methodologies}

\subsection{Firn sampling}

Firn air samples were collected at the NEEM site, Greenland $\left(77.45^{\circ} \mathrm{N}, 51.07^{\circ} \mathrm{W}, 2484 \mathrm{~m}\right.$ a.s.l) from two boreholes between 14 and 30 July 2008 ("2008 EU hole" and "2008 US hole"). Further samples were collected from another NEEM borehole during July 2009 ("2009 hole"). The 2008 EU hole was sampled using the firn air system of the University of Bern (Schwander et al., 1993), and the US hole, sampled using the US firn air system (Battle et al., 1996). The alkane measurements used in this work - originally reported in Helmig et al. (2014b) - come from a combination of the 2008 EU and US holes and the 2009 hole with the exception of the pentanes, which come only from the $2008 \mathrm{EU}$ and US holes. The alkyl nitrate samples come only from the $2008 \mathrm{EU}$ hole. Full sampling details are available in Helmig et al. (2014b) and Buizert et al. (2012).

\subsection{Firn analysis}

The firn air samples from the EU hole at NEEM were analysed for alkyl nitrates at the University of East Anglia (UEA) using a gas chromatography mass spectrometer (GC-MS) in negative ion chemical ionisation mode (GC-NICI-MS) (e.g. Worton et al., 2008).

2-pentyl nitrate and 3-pentyl nitrate are presented together as $2+3$-pentyl nitrate because the two are not baseline separated in the chromatogram.

The NEEM samples were analysed using the UEA calibration scale. This was converted to the NCAR scale (against which the North GRIP 2-butyl nitrate and 2+3-pentyl nitrate samples are calibrated) for direct comparison with the North GRIP atmospheric histories from Worton et al. (2012) and with the in situ measurements at Summit Station by the University of California, Irvine (UCI) (Swanson et al., 2003; Dibb et al., 2007). This scaling was based on an intercomparison between the UEA and NCAR standards in 2005 and 2012/2013. These led to a rescaling of the UEA 2-butyl nitrate values by 1.245 and $2+3$-pentyl nitrate by 1.409 . The measurements of 3-methyl-2-butyl nitrate were not rescaled 
as the North GRIP measurements were made on the UEA scale.

Firn air samples from the EU hole at NEEM were analysed for alkanes at the Max Planck Institute Laboratory (MPI) by gas chromatography with flame ionisation detection (GCFID) (see Baker et al., 2010 for further details). At the Institute of Arctic and Alpine Research (INSTAAR) firn air samples were analysed from both the EU and US holes at NEEM for alkanes by GC-FID (see Pollmann et al., 2008 and Helmig et al., 2014b for further details).

\subsection{Firn modelling}

The air sampled from any given depth in the firn column is representative of a range of ages because of the interconnected nature of the firn. Firn models can be used to derive the atmospheric history of a gas from measurements of air trapped in the firn. The extent and rate at which the gas diffuses through the firn depends on the diffusivity profile of the firn, the diffusivity coefficient of the gas and on the gravitational fractionation (caused by the molecular weight) of the gas. The diffusion profile is different for every firn site.

To determine the atmospheric history of a gas from firn air measurements, the firn diffusion profiles must first be constrained. This is done using a series of reference gases with well-known atmospheric histories. At NEEM the reference gases used were $\mathrm{CO}_{2}, \mathrm{CH}_{4}, \mathrm{SF}_{6}$, HFC-134a, CFC-11, CFC12, CFC-113, and $\mathrm{CH}_{3} \mathrm{CCl}_{3}$, as well as ${ }^{14} \mathrm{CO}_{2}$ (Witrant et al., 2012).

Each gas also has a different diffusion rate through the firn based on its molecular structure; this is called the diffusion coefficient. The diffusion coefficient is calculated relative to a reference gas, generally $\mathrm{CO}_{2}$. Different methods have been reported for the calculation of these diffusion coefficients (e.g. Chen and Othmer, 1962; Fuller et al., 1966). The diffusion coefficients of the alkyl nitrates were calculated using the method of Fuller et al. (1966) based on the sum of the Le Bas molar volumes of the molecule. Model runs were also performed using diffusion coefficients for the alkyl nitrates calculated using the Chen and Othmer method. These coefficients are $\sim 10 \%$ lower than those calculated using the Fuller method. However, the atmospheric scenarios derived from the modelling are very similar, well within the $2 \sigma$ uncertainty envelopes presented in Fig. 2. The diffusion coefficients used for the firn modelling for each molecule within this work are given in Table 1.

The inverse model used for the atmospheric history reconstructions was the most recent version of the LGGE-GIPSA atmospheric trend reconstruction model described in Witrant and Martinerie (2013).

The atmospheric mole fraction derived from the firn reconstructions represents an annual mean. The alkanes and alkyl nitrates examined in this work have a strong atmospheric seasonality due to changes in their chemical lifetimes driven by seasonal variability in $\mathrm{OH}$ concentration in the air
Table 1. Diffusion coefficients used in the firn modelling, calculated from Le Bas molecular volumes using the method of Fuller et al. (1966).

\begin{tabular}{lr}
\hline Compound & $\begin{array}{r}\text { Diffusion coefficient } \\
\text { relative to } \mathrm{CO}_{2}\end{array}$ \\
\hline 2-butyl nitrate & 0.467 \\
2+3-pentyl nitrates & 0.428 \\
3-methyl-2-butyl nitrate & 0.428 \\
\hline
\end{tabular}

masses in which they are transported to the Arctic. Thus the seasonal cycle of both species follows a roughly sinusoidal curve with a peak in the late winter (March) and a trough in midsummer (July-August) (Swanson et al., 2003). Consequently, changes to the firn-derived mole fractions are likely to be dominated by changes to wintertime atmospheric concentrations.

This model cannot take into account the seasonality in the signal that is preserved in the upper part of a firn profile. Therefore, measurements above a certain depth must be excluded from the model input. It is noted that the latter part (post-1995) of the model-derived scenarios for 2+3-pentyl nitrate is rather sensitive to the inclusion or exclusion of the measurement at $34.72 \mathrm{~m}$ (the shallowest measurement used). The scenarios presented in this work are based on including this measurement.

\section{Alkyl nitrate trends}

Atmospheric histories of the three alkyl nitrates 2-butyl nitrate, 2+3-pentyl nitrate, and 3-methyl-2-butyl nitrate (formed from n-butane, n-pentane, and iso-pentane respectively) derived from firn air measurements at NEEM are shown in Fig. 2. The records of all three alkyl nitrates show similar features (as would be expected from the similar sources and sinks). All show a steep increase in mixing ratio from the 1970s to the 1990s with increases of a factor of 3-4. The peak in the 1990s is followed by a steep decline to the sampling date of 2008 .

Figure 2 also shows the atmospheric histories of the same three alkyl nitrates derived from firn air from North GRIP, Greenland, up to 2001, presented in Worton et al. (2012) (pink shaded area). There is very good agreement between the derived trends at the two sites. Differences can be attributed to the limited number of measurements at both sites, possible drift in the calibration standard used, and uncertainties in the firn modelling. Both sites show the same large increase in mixing ratios from the 1970s to the 1990s. Importantly, the NEEM records show that the turnover and subsequent decline in mixing ratios, the beginnings of which were evident in the North GRIP records, appears to continue through the 2000s. However, as noted in Sect. 2.3, the derived atmospheric history of $2+3$-pentyl nitrate is sensitive 

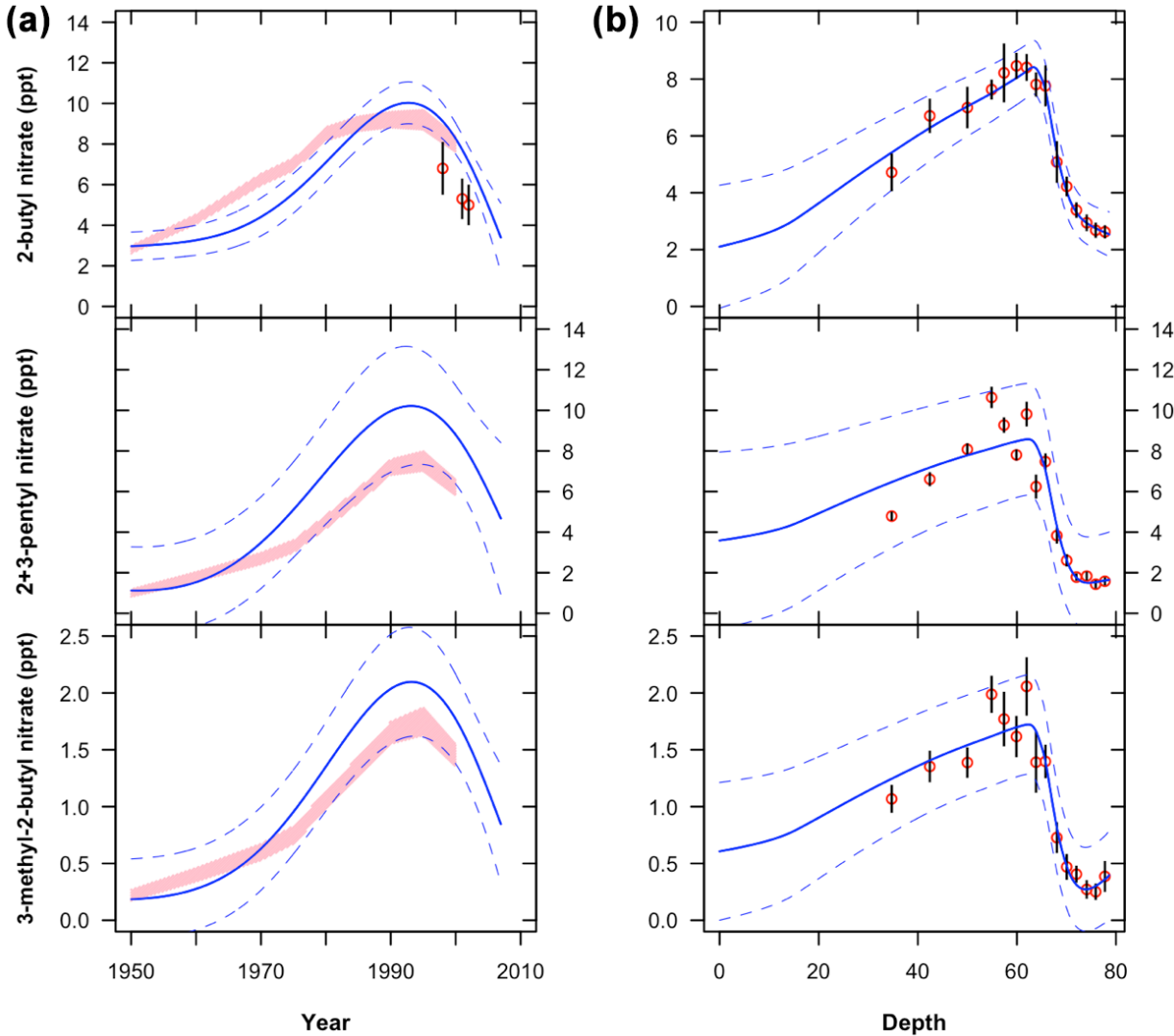

Figure 2. Concentration-depth profiles in the firn and the model-derived atmospheric histories. (b) The concentration-depth profiles measured in the firn (ppt): red open circles are measured mixing ratios (ppt) with error bars indicating the $2 \sigma$ uncertainty; solid blue line are best fit of the firn model, dashed blue lines indicate the $2 \sigma$ combined analytical and model uncertainties. (a) Atmospheric histories of the alkyl nitrates derived from the firn air measurements using the inverse modelling technique described within (solid blue lines). Dashed lines represent the $2 \sigma$ confidence margins of the model calculations, combining the analytical and model uncertainties. Pink shaded area represents atmospheric histories presented in Worton et al. (2012) derived from firn air measurements at North GRIP, Greenland. Red open circles show the annual average of in situ measurements at Summit Station, Greenland (see text for details) with $1 \sigma$ uncertainty.

to the inclusion of the measurement at $34.72 \mathrm{~m}$. A scenario that did not include this measurement was almost flat from 1995 to 2008 rather than declining as in Fig. 2.

There are very limited in situ measurements of alkyl nitrates in the Arctic and even fewer that cover a whole seasonal cycle. Swanson et al. (2003) reported the seasonal cycle of 2-butyl nitrate at Summit Station, Greenland $\left(72.34^{\circ} \mathrm{N}\right.$, $38.29^{\circ} \mathrm{W}, 3250 \mathrm{~m}$ a.s.l), from June 1997 to June 1998 based on samples collected roughly every 2 days. Dibb et al. (2007) reported monthly mean measurements of 2-butyl nitrate for the period June 2000 through to August 2002 based on samples taken roughly weekly also from Summit Station. In order to compare these in situ measurements to output derived from the firn measurements the annual mean is taken. This is because the firn smoothes out the seasonality and represents the annual mean of mixing ratios. Calculating the 2-butyl nitrate annual mean for the three periods 1997-1998 (6.8 ppt), 2000-2001 (5.3 ppt), and 2001-2002 (5.0 ppt) gives values that can be compared to the output from the firn model for 2- butyl nitrate. These agree with the firn model output in terms of absolute mixing ratios of 2-butyl nitrate during this period (5-8 ppt) (Fig. 2). They also show a declining trend through the period, in agreement with the firn model output, though this is not statistically significant within the uncertainties.

Considering Reactions (R13)-(R16), the trends in the alkyl nitrate mixing ratios (Fig. 2) could be caused by the following:

i. changes to the atmospheric mixing ratios of the parent alkanes;

ii. changes to $[\mathrm{OH}] t$, where $t$ is time since emission of the alkane. i.e. the amount of photochemical processing that the air mass in which the alkyl nitrates are being formed undergoes before reaching the Arctic;

iii. changes to the production efficiency of the alkyl nitrates, i.e. whether the peroxy radical reacts with $\mathrm{NO}$ (Reaction R14) or with $\mathrm{HO}_{2}$ (Reaction R11); 


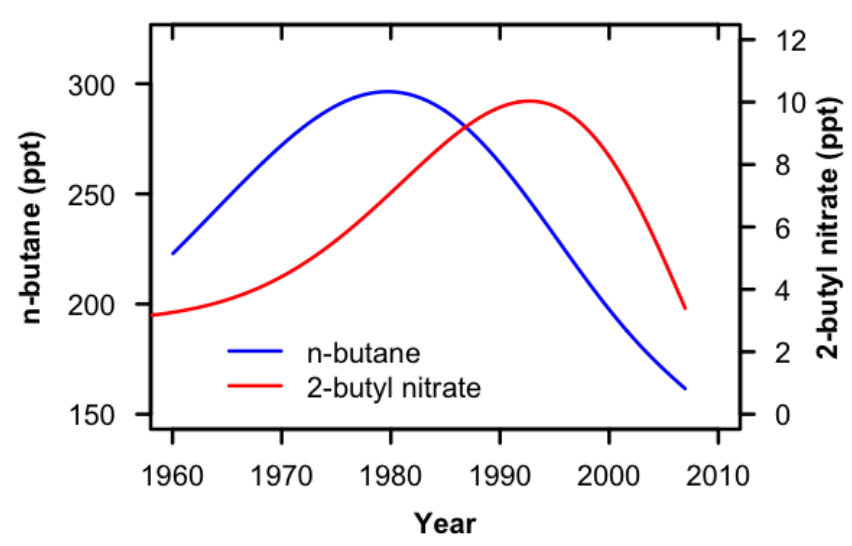

Figure 3. Atmospheric histories of 2-butyl nitrate (red) and its parent alkane, n-butane (blue), derived from firn measurements at NEEM, Greenland.

iv. changes to the alkyl nitrate sinks, i.e. changes in $[\mathrm{OH}]$ or radiation.

Concerning point (i), the peak in alkyl nitrate mixing ratios in the 1990s is not contemporaneous with that of the parent alkanes $(\sim 1980-$ Fig. 3$)$. This suggests that the changes to the alkyl nitrate mixing ratios are not being primarily driven by changes to the parent alkane. By considering the ratio of the alkyl nitrate to its parent hydrocarbon, using the firnderived alkane trends from NEEM presented in Helmig et al. (2014b), we can effectively remove the effect of changes to the parent hydrocarbon from the alkyl nitrate signal. This is done in Sect. 4.

Concerning point (iv), there is evidence for global dimming (i.e. a decrease in surface solar radiation) of about $5 \%$ between 1960 and 1990 in the Northern Hemisphere. However, this began to turn around during the mid-1980s and there was a brightening trend between 1985 and 2000 (Wild et al., 2005). This minor change to the alkyl nitrate sink is unlikely to have had a noticeable effect on mixing ratios.

Points (ii), (iii), and (iv) are discussed further in the following sections.

\section{Ratios of alkyl nitrate to parent alkane}

Bertman et al. (1995) presented a mathematical equation to describe the production of alkyl nitrates in a $\mathrm{NO}_{x}$-rich environment (Eq. 1 assumes an initial zero mixing ratio for alkyl nitrates).

$\frac{\left[\mathrm{RONO}_{2}\right]}{[\mathrm{RH}]}=\frac{\beta k_{A}}{\left(k_{B}-k_{A}\right)}\left(1-e^{\left(k_{A}-k_{B}\right) t}\right)$

Here, $\beta=\alpha_{13} \alpha_{14}, k_{A}=k_{13}[\mathrm{OH}], k_{B}=k_{15}[\mathrm{OH}]+j_{16}$; subscript numbers refer to reactions given in the introduction. In this equation, $[\mathrm{OH}]$ is assumed to be a constant. Similarly for the purposes of this work, $[\mathrm{OH}]$ is assumed to rep- resent an average $[\mathrm{OH}],[\overline{\mathrm{OH}}]$, to which the air mass is exposed during transport from the source region to the Arctic, i.e. $1 / t \cdot \int[\mathrm{OH}] \mathrm{d} t$.

Bertman et al. (1995) derived Eq. (1) by integrating the rate equation for $\left[\mathrm{RONO}_{2}\right]$ assuming a $\mathrm{NO}_{x}$-rich environment (Eq. 2).

$\frac{d\left[\mathrm{RONO}_{2}\right]}{\mathrm{d} t}=\beta k_{A}[\mathrm{RH}]-k_{B}\left[\mathrm{RONO}_{2}\right]$

We extend Eq. (2) to include the possibility of alkyl nitrate production at less than $100 \%$ efficiency, in a non- $\mathrm{NO}_{x}$ rich environment, i.e. that the peroxy radical, $\mathrm{RO}_{2}$, formed may react with something other than NO. This is achieved by the inclusion of the term $k_{14}[\mathrm{NO}] /\left(k_{14}[\mathrm{NO}]+\right.$ other $\mathrm{RO}_{2}$ sinks). In high- $\mathrm{NO}_{x}$ environments, this value is $\cong 1$. However, in lower $\mathrm{NO}_{x}$ environments, other sinks for the peroxy radical, $\mathrm{RO}_{2}$, will compete with NO. In reality the term $k_{11}\left[\mathrm{HO}_{2}\right]$ is likely to dominate the "other $\mathrm{RO}_{2}$ sinks" term in a background environment. The only other species likely to be present at high enough concentrations to compete with the $\mathrm{RO}_{2}+\mathrm{HO}_{2}$ reaction is the methyl peroxy radical $\left(\mathrm{CH}_{3} \mathrm{O}_{2}\right)$, which may be present at similar concentrations to $\mathrm{HO}_{2}$, but the reaction rate of $\mathrm{CH}_{3} \mathrm{O}_{2}$ with other alkyl peroxy radicals larger than $\mathrm{CH}_{3} \mathrm{O}_{2}$ is $\leq 2 \times 10^{-13} \mathrm{~cm}^{-3} \mathrm{~s}^{-1}$ (IUPAC), 2 orders of magnitude slower than the reaction with $\mathrm{HO}_{2}$ (IUPAC). Hence in Eq. (3) we extend Eq. (2) by including the term $k_{14}[\mathrm{NO}] /\left(k_{14}[\mathrm{NO}]+k_{11}\left[\mathrm{HO}_{2}\right]\right)$.

$\frac{d\left[\mathrm{RONO}_{2}\right]}{\mathrm{d} t}=\frac{\beta k_{A}[\mathrm{RH}] k_{14}[\mathrm{NO}]}{k_{14}[\mathrm{NO}]+k_{11}\left[\mathrm{HO}_{2}\right]}-k_{B}\left[\mathrm{RONO}_{2}\right]$

For the purposes of our calculations, $k_{14}[\mathrm{NO}] /\left(k_{14}[\mathrm{NO}]+k_{11}\left[\mathrm{HO}_{2}\right]\right)$ is assumed (in the same way as $[\mathrm{OH}])$ to represent an integrated value for this ratio during transport of the air mass from the source region to the Arctic, i.e. $1 / t \cdot \int k_{14}[\mathrm{NO}] /\left(k_{14}[\mathrm{NO}]+k_{11}\left[\mathrm{HO}_{2}\right]\right) \mathrm{d} t$. We denote this term $\gamma$ (Eq. 4).

$$
\begin{aligned}
\gamma & =\overline{\left(\frac{k_{14}[\mathrm{NO}]}{k_{14}[\mathrm{NO}]+k_{11}\left[\mathrm{HO}_{2}\right]}\right)} \\
& =\text { mean alkyl nitrate production efficiency }
\end{aligned}
$$

$k_{14}[\mathrm{NO}] /\left(k_{14}[\mathrm{NO}]+k_{11}\left[\mathrm{HO}_{2}\right]\right)$ would not be expected to be constant in reality since [NO] is likely to change by orders of magnitude during transport, with values of the order of $2.5 \times 10^{11} \mathrm{~cm}^{-3}$ close to the emissions source, and falling to $\sim 1 \times 10^{8} \mathrm{~cm}^{-3}$ further from the source. Changes to the ratio $k_{14}[\mathrm{NO}] /\left(k_{14}[\mathrm{NO}]+k_{11}\left[\mathrm{HO}_{2}\right]\right)$ at different times along the air mass trajectory will affect $d\left[\mathrm{RONO}_{2}\right] / \mathrm{d} t$ at that time differently because $d\left[\mathrm{RONO}_{2}\right] / \mathrm{d} t$ is also driven by $[\mathrm{RH}]$, which is a function of time. However, the assumption of $\mathrm{k} 14[\mathrm{NO}]=(\mathrm{k} 14[\mathrm{NO}]+\mathrm{k} 11[\mathrm{HO} 2])$ as an integrated value through time, i.e. $\gamma$, leads to uncertainties in the calculated $\left[\mathrm{RONO}_{2}\right] /[\mathrm{RH}]$, at time $t=10$ days, of the order of $5 \%$ (see Supplement). The observed changes in $\left[\mathrm{RONO}_{2}\right] /[\mathrm{RH}]$ 
in the firn are considerably larger than this, of the order of a factor of 3-5. Hence we consider the assumption of $\gamma$ as a constant to be a reasonable assumption for the sake of making the problem tractable and that the changes to $\gamma$ that we calculate in the paper are not an artefact of this assumption.

Since $\gamma$ is treated as a constant, integration of Eq. (3) gives an equation the same as Eq. (1) from Bertman et al. (1995) except with the addition of the term $\gamma$ (Eq. 5).

$\frac{\left[\mathrm{RONO}_{2}\right]}{[\mathrm{RH}]}=\frac{\gamma \beta k_{A}}{\left(k_{B}-k_{A}\right)}\left(1-e^{\left(k_{A}-k_{B}\right) t}\right)$

Atmospheric histories of the three parent alkanes of the alkyl nitrates presented in Fig. 2 were presented in Helmig et al. (2014b) - Fig. 7 (n-butane, n-pentane, iso-pentane). These are used here, in conjunction with the alkyl nitrate histories in Fig. 2, to determine trends of the ratio $\left[\mathrm{RONO}_{2}\right] /[\mathrm{RH}]$ for each alkyl nitrate-alkane pair. By rearranging Eq. (5), we can then probe two of the possible causes for the observed alkyl nitrate trends. Firstly, that the mean production efficiency (i.e. $\gamma$ ) has changed over the time period of the firn record. Secondly, that the processing of the air mass, i.e. mean $\mathrm{OH}$ concentration, $[\overline{\mathrm{OH}}]$, multiplied by the transport time from source regions to the Arctic, $t$, has changed.

\section{Changes to the production efficiency of the alkyl nitrates}

In an urban environment, daytime [NO] can range from 10 to a few hundred ppb. In this case, the production efficiency of the alkyl nitrates $\approx 1$, i.e. all of the alkyl peroxy radicals formed in Reaction (R13) go on to form alkyl nitrates at a yield determined by the branching ratio $\alpha_{13}$. However, in rural and more remote regions of the atmosphere, daytime [NO] ranges from 1 to $100 \mathrm{ppt}$. At these mixing ratios $k_{14}[\mathrm{NO}] /\left(k_{14}[\mathrm{NO}]+k_{11}\left[\mathrm{HO}_{2}\right]\right)$ would be expected to vary between around 0.3 and 1 , assuming a daytime $\left[\mathrm{HO}_{2}\right]=$ $2 \times 10^{7}$ molecules $\mathrm{cm}^{-3}$ (wintertime - the alkyl nitrate and alkane signals in the firn are dominated by wintertime concentrations). Changes to $[\mathrm{NO}]$ or $\left[\mathrm{HO}_{2}\right]$ in these remote environments will affect the production efficiency of the alkyl nitrates. Since the term $\gamma$ is an average across the whole transport time it reflects both the urban and remote environments.

Equation (6) is a rearrangement of Eq. (5) from which historic changes to $\gamma$ can be calculated using the measured changes to the $\left[\mathrm{RONO}_{2}\right] /[\mathrm{RH}]$ ratio (assuming that the photochemical processing, $[\overline{\mathrm{OH}}] t$, has remained constant through time). All rate constants and branching ratios used in the calculations are taken from MCMv3.3.1 (mcm.leeds.ac. uk; Jenkin et al., 1997) (see Table S2, Supplement) assuming a temperature of $273 \mathrm{~K}$. The magnitude of the diurnal photolysis sink of the alkyl nitrates, $j_{16}$, will vary with emission region and during transport. $j_{16}$ is included in the term $\lambda$, which represents the ratio $j_{16} / k_{15} \overline{[\mathrm{OH}]} . \lambda$ is assumed to be 1 in Fig. 4, i.e. $j_{16}=k_{15} \overline{[\mathrm{OH}]}$. The sensitivity to the magnitude

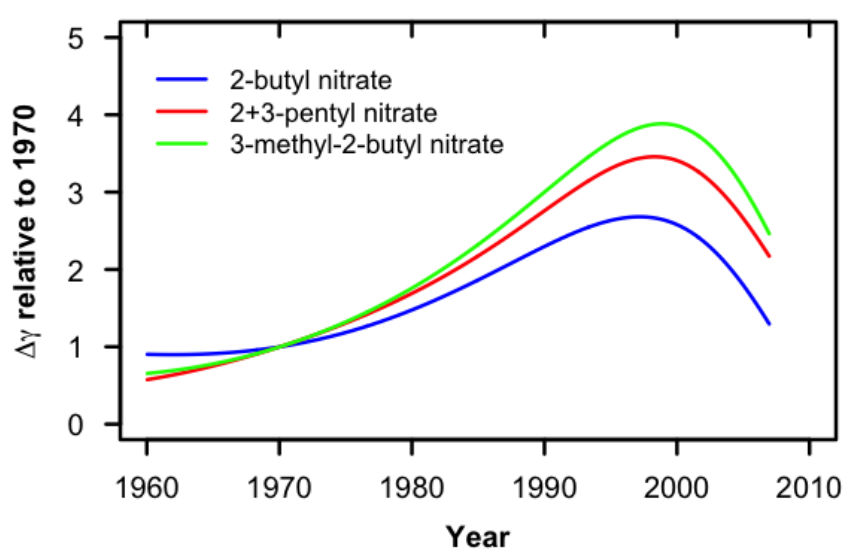

Figure 4. The trend in the mean alkyl nitrate production efficiency, $\gamma$, of the air masses in which the alkyl nitrates were formed, calculated using Equation E5 for each of three alkyl nitratealkane pairs, relative to 1970 values. This assumes that the amount of photochemical processing, $[\overline{\mathrm{OH}}] t$, remained constant at $5 \times$ $10^{11}$ molecules $\mathrm{cm}^{-3} \mathrm{~s}$. All rate constants and branching ratios used in the calculations are taken from MCMv3.3.1 (mcm.leeds.ac.uk) assuming a temperature of $273 \mathrm{~K}$. The mean diurnally averaged photolysis sink $j_{16}$ was assumed to be equal to the mean $\mathrm{OH}$ sink, $k_{15}[\overline{\mathrm{OH}}]$.

of this sink is discussed further in the Supplement.

$\gamma=\frac{\left[\operatorname{RONO}_{2}\right]\left(k_{15}(1+\lambda)-k_{13}\right)}{[\mathrm{RH}] \beta k_{13}\left(1-e^{\left(k_{A}-k_{B}\right) t}\right)}$

Figure 4 shows the historical trend in mean alkyl nitrate production efficiency, $\gamma$, relative to 1970 , calculated using Eq. (6) if $\overline{[\mathrm{OH}]} t$ is assumed to have remained constant during this period. A value of $5 \times 10^{11}$ molecules $\mathrm{cm}^{-3} \mathrm{~s}$ is used for the constant $\overline{[\mathrm{OH}]} t$. This is based on a mean transport time of air masses from Europe (from where the majority of wintertime pollutants are transported to the Arctic - see Sect. 6.1) to the Arctic in the winter of 10 days (Stohl, 2006), and a mean wintertime $[\mathrm{OH}]$ of $\sim 6 \times 10^{5} \mathrm{~cm}^{-3}$ (in reasonable agreement with that derived by Derwent et al. (2012) for the North Atlantic in wintertime). However, it is noted that the relative change in $\gamma$ shown in Fig. 4 is independent of the value used for $\overline{[\mathrm{OH}]} t$.

The trend in the mean production efficiency of the alkyl nitrates, $\gamma$, relative to 1970 values, shows similar features to those of the alkyl nitrate trends. The ratio increases by a factor of between 2.5 (2-butyl nitrate) and 4 (3-methyl-2butyl nitrate) from the 1970s to the late 1990s and then subsequently declines.

This analysis suggests that the observed changes to the $\left[\mathrm{RONO}_{2}\right] /[\mathrm{RH}]$ ratio in the firn could be explained by changes to $\gamma$. This is driven by changes to the $[\mathrm{NO}] /\left[\mathrm{HO}_{2}\right]$ ratio experienced by air masses in transport to the Arctic. We now investigate whether trends in processes that could drive this ratio are consistent with this scenario, i.e. how $\mathrm{NO}_{x}$ concentrations may have changed. 


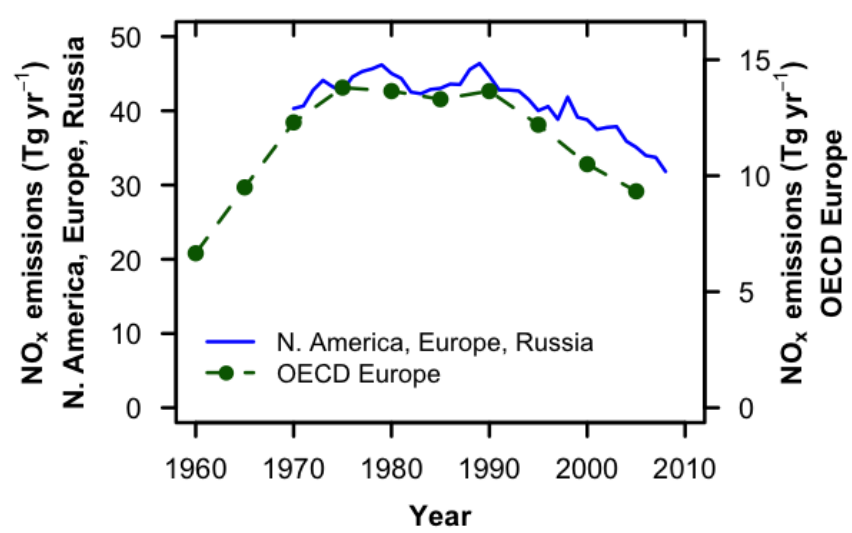

Figure 5. Blue solid line (left axis) shows the trend in $\mathrm{NO}_{x}$ emissions $\left(\mathrm{Tg} \mathrm{yr}^{-1}\right)$ from North America, Europe, and Russia for the period 1970 to 2008 (EDGAR v4.2, http://edgar.jrc.ec.europa.eu). Green points (and dashed line) (right axis) show OECD Europe $\mathrm{NO}_{x}$ emissions $\left(\mathrm{Tg} \mathrm{yr}^{-1}\right)$ from Vestreng et al. (2009).

\subsection{Changes to atmospheric $\mathrm{NO}_{x}$ concentrations}

\subsubsection{NO $x$ sources}

The atmospheric $\mathrm{NO}_{x}$ concentration is determined by the relative magnitudes of the sources and sinks. The main sources of $\mathrm{NO}_{x}$ in the Northern Hemisphere are anthropogenic emissions from fossil fuel use, power stations and transport (Olivier and Berdowski et al., 2001; Olivier et al., 2001).

Figure 5 shows how $\mathrm{NO}_{x}$ emissions from North America, Europe, and Russia have varied between 1970 and 2008, taken from the bottom-up estimates of the EDGAR database (EDGAR v4.2 (EC-JRC/PBL, 2011), http://edgar. jrc.ec.europa.eu). Emissions were fairly constant between 1970 and 1990 and then fell by about $25 \%$ from 1990 to 2008. This is in good agreement with the $\mathrm{NO}_{x}$ emission trends for OECD Europe presented in Vestreng et al. (2009).

Assuming that these bottom-up emissions estimates are correct in the timing of the $\mathrm{NO}_{x}$ emissions changes, it seems unlikely that an increase in the alkyl nitrate production efficiency during the period 1970 to the late 1990s could have been driven primarily by changing $\mathrm{NO}_{x}$ emissions.

A decline in the alkyl nitrate production efficiency after the late 1990s, on the other hand, may well have been driven by decreasing $\mathrm{NO}_{x}$ emissions. Measurements at a range of UK sites showed a decrease in $\mathrm{NO}_{x}$ concentrations from 1996 (the beginning of the reported measurements) to 2002-2004, of $1-3.5 \%$ per year, depending on the site (Carslaw et al., 2011). During the same period, the fraction of the $\mathrm{NO}_{x}$ that is $\mathrm{NO}_{2}\left(f-\mathrm{NO}_{2}\right)$ roughly doubled, suggesting that $\mathrm{NO}$ has decreased by more than $\mathrm{NO}_{x}$ concentrations. Recent trends at many European sites show similar trends with small decreases in $\mathrm{NO}_{x}$ between 1999 and 2007 (the period for which measurements are available) but level or increasing $\mathrm{NO}_{2}$ over the same period (Carslaw et al., 2011; Gilge et al., 2010).
Declining $\mathrm{NO}_{x}$ emissions have been used to explain these trends in measured concentrations. However, the decline in these ambient concentrations is not as large as would be expected using current emission inventories (Carslaw et al., 2011).

\subsubsection{NO $\mathrm{N}_{x} \operatorname{sinks}$}

At mid-high latitudes in the daytime during the summer, the main sink for $\mathrm{NO}_{x}$ is the reaction of $\mathrm{NO}_{2}$ with $\mathrm{OH}$. This reaction produces nitric acid $\left(\mathrm{HNO}_{3}\right)$, much of which is then removed from the atmosphere by wet deposition. However, at night and during the winter months, when daily mean $[\mathrm{OH}]$ is more than an order of magnitude lower than during the summer (e.g. Derwent et al., 2012), the dominant $\mathrm{NO}_{x}$ sink is the conversion of dinitrogen pentoxide $\left(\mathrm{N}_{2} \mathrm{O}_{5}\right)$ to $\mathrm{HNO}_{3}$. This only occurs when photolysis is low, allowing $\mathrm{NO}_{3}$ (formed from the reaction of $\mathrm{NO}_{2}$ with $\mathrm{O}_{3}$ ) to build up. This $\mathrm{NO}_{3}$ reacts with $\mathrm{NO}_{2}$ to form $\mathrm{N}_{2} \mathrm{O}_{5}$. While the reaction of $\mathrm{N}_{2} \mathrm{O}_{5}$ with $\mathrm{H}_{2} \mathrm{O}$ is slow in the gas phase (Tuazon et al., 1983), it occurs rapidly in aerosol.

A modelling study by Dentener and Crutzen (1993) predicted that changes to the loss of $\mathrm{NO}_{x}$ via sulfate aerosol could have a significant effect on Northern Hemisphere $\mathrm{NO}_{x}$ concentrations and that these changes would also affect $\mathrm{O}_{3}$ and $\mathrm{OH}$ concentrations. Subsequent modelling studies, though often focussing on remaining uncertainties in the uptake coefficients of $\mathrm{N}_{2} \mathrm{O}_{5}$ to aerosol, have broadly agreed with the magnitude of the $\mathrm{NO}_{x}$ changes suggested by Dentener and Crutzen (Brown and Stutz, 2012).

There has been a large decrease in sulfate aerosol observed in Europe and the United States since 1980 (Berglen et al., 2007; Turnock et al., 2015). Figure 6 shows the measured trend in wintertime (DJF) sulfate mass concentration presented in Turnock et al. (2015), with decreases of about $75 \%$ from 1979 to 2005 . This decreasing trend has been driven by $\mathrm{a} \sim 70 \%$ decrease in $\mathrm{SO}_{2}$ emissions (Smith et al., 2011) from these regions (Fig. 6). It is noted that while global $\mathrm{SO}_{2}$ emissions have only decreased about $15 \%$ from the peak in the 1970s due to rapidly increasing emissions in eastern Asia in recent decades, sulfate aerosol has a lifetime of about 5 days in the troposphere (and $\mathrm{SO}_{2}$ of about 1 day) (Stevenson et al., 2003) and so aerosol concentrations will be largely driven by regional $\mathrm{SO}_{2}$ emissions.

These large decreases in sulfate aerosol in Europe and the US (the main source regions for air masses arriving in the Arctic in the winter) may be expected to have led to a decrease in $\mathrm{NO}_{x}$ removal by $\mathrm{N}_{2} \mathrm{O}_{5}$ hydrolysis, and hence to an increase in the $\mathrm{NO}_{x}$ lifetime and atmospheric $\left[\mathrm{NO}_{x}\right]$, either through long-term changes to the total sulfate aerosol burden (Turnock et al., 2015) or long-term changes to particle acidity driven by reductions in sulfate (e.g. Murphy et al., 2017). The time period of decreasing $\mathrm{SO}_{2}$ emissions and sulfate aerosol is broadly in line with the derived steep increase in the alkyl nitrate production efficiency. 


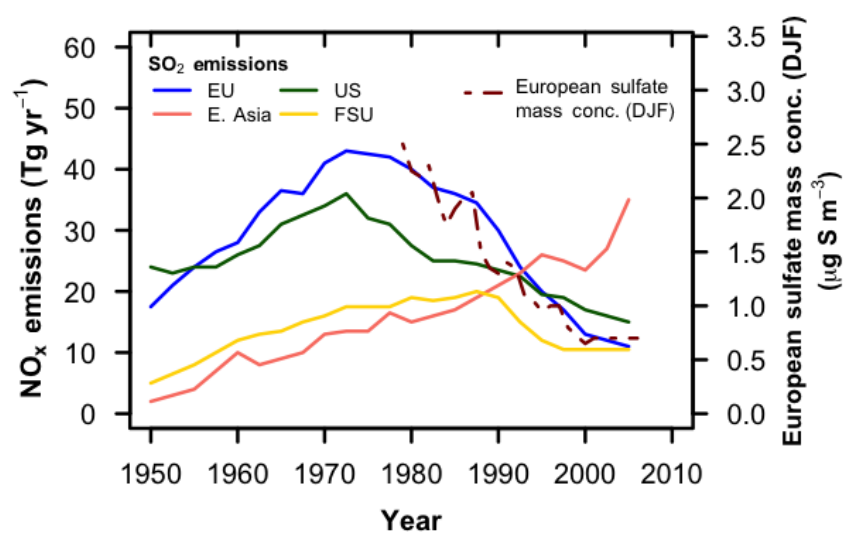

Figure 6. $\mathrm{SO}_{2}$ emissions $\left(\mathrm{Tg} \mathrm{yr}^{-1}\right)$ 1950-2005 from Smith et al. (2011), and mean European sulfate mass concentration $\left(\mu \mathrm{g} \mathrm{S} \mathrm{m}^{-3}\right.$ ) in winter (DJF) from Turnock et al. (2015). $\mathrm{SO}_{2}$ emissions: blue is Europe, green is North America (US and Canada), gold is the former Soviet Union (Russia, Ukraine, and others), pink is eastern Asia (China, Japan, South Korea, and others). Brown dashed line is the mean European sulfate mass concentration in winter (DJF).

However, work remains ongoing to determine the exact effect of a number of parameters (e.g. relative humidity, particulate organic / sulfate ratio, particle acidity) on the $\mathrm{N}_{2} \mathrm{O}_{5}$ uptake coefficient, and thus the efficacy of the reaction, and the extent to which changing sulfate content and abundance of aerosol would be expected to affect the uptake coefficient and thus oxidant concentrations (Brown and Stutz, 2012).

\section{Changes to photochemical oxidation}

An alternative explanation for the observed alkyl nitrate trends is that the amount of photochemical processing of the air mass changed during the period of study. An increase in processing could be caused by a change in either the concentration of the $\mathrm{OH}$ radical (assuming photolysis to have remained constant) or by an increase in the transport time of the air mass from the source region to the Arctic.

Equation (7) is a rearrangement of Eq. (6) from which historic changes to the photochemical processing, $\overline{[\mathrm{OH}]} t$, can be calculated using the measured changes to the $\left[\mathrm{RONO}_{2}\right] /[\mathrm{RH}]$ ratio, assuming that $\gamma$ has remained constant.

$\overline{[\mathrm{OH}]} t=$

$\ln \left(1-\frac{\left[\mathrm{RONO}_{2}\right]\left(k_{15}(1+\lambda)-k_{13}\right)}{[\mathrm{RH}] \gamma \beta k_{13}}\right) /\left(k_{13}-k_{15}(1+\lambda)\right)$

Figure 7 shows the trends in $\overline{[\mathrm{OH}]} t$ derived from the alkyl nitrate-alkane pairs if a constant value for $\gamma$ is assumed. The value used for the constant $\gamma$ for each alkyl nitrate was the mean value derived in Fig. 4 for the period 1960-2007 (0.31

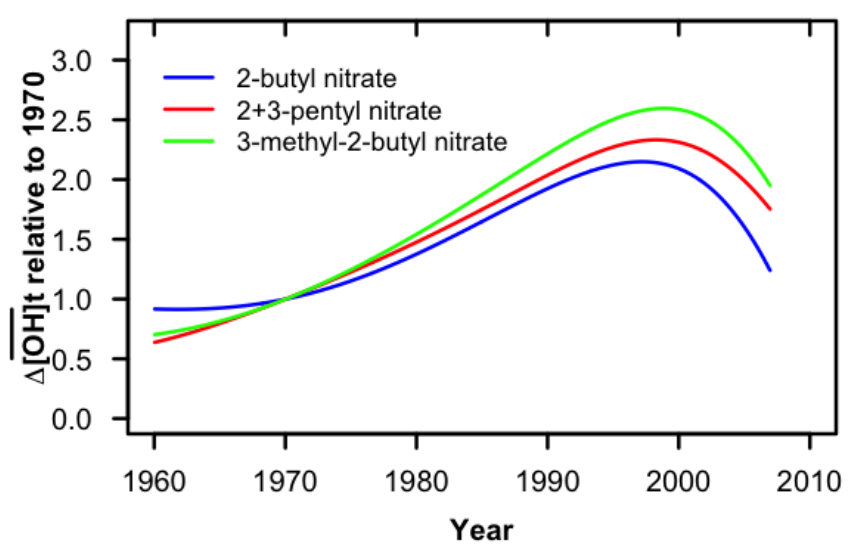

Figure 7. The trend in $\overline{[\mathrm{OH}]} t$ calculated using Eq. (6) for each of three alkyl nitrate-alkane pairs assuming a constant value for $\gamma$.

for 2-butyl nitrate, 0.34 for 2+3-pentyl nitrate, 0.17 for 3methyl-2-butyl nitrate).

Equation (7) also has $[\mathrm{OH}]$ terms on the right-hand side of the equation, incorporated in $\lambda$. The results in Fig. 7 are determined through an iterative process of fitting a polynomial to the trend calculated using an a priori assumption that $\lambda=1$ for the whole time period. The calculation is then repeated with a temporally varying value for $\lambda$ using this fit to determine the changes. This process converges towards the unique solution presented in Fig. 7. For example, in Fig. 7 for 2-butyl nitrate, in 1970 the assumed value of $\lambda$ is 1 , at the peak of $\Delta \overline{[\mathrm{OH}]} t$ in 1997, when $\Delta \overline{[\mathrm{OH}]} t=2.1$, the value of $\lambda$ is $0.46(1 / 2.1)$.

Figure 7 shows that the observed $\left[\mathrm{RONO}_{2}\right] /[\mathrm{RH}]$ ratios between around 1970 and the late 1990s could be explained by a relative change in $\overline{[\mathrm{OH}]} t$ of a factor of between 2.1 (2butyl nitrate) and 2.6 (3-methyl-2-butyl nitrate). The sensitivity of these calculated values to the assumed value for $\gamma$ and for $j_{16}$ in 1970 is discussed in the Supplement.

\subsection{Air mass transport time to the arctic}

The transport time, $t$, of pollutants to the Arctic from the source is dependent on (i) the atmospheric transport patterns, and (ii) the source regions of the pollutants.

Concerning (i), Kahl et al. (1999) have suggested that there is a decadal-scale (4-14 years) variability in transport patterns of pollutants from the $\mathrm{NH}$ to the Arctic but note no long-term trend. Hirdman et al. (2010) note that while changes to transport patterns can explain much of the interannual variability of Arctic concentrations of black carbon and sulfate aerosol (pollutants with similar source regions to the alkanes), they played only a minor role in long-term changes. Eckhardt et al. (2003) have shown that transport of pollutants to the Arctic from European and US source regions is more rapid during positive phases of the weather pattern, the North Atlantic Oscillation (NAO). During the period 
1960-1980 the NAO was predominantly in a negative phase in winter, between 1980 and 2000 it was predominantly in a positive phase, and since 2000 neither phase has been dominant (Hurrell and Deser, 2010). This suggests that there was more rapid transport of pollutants to the Arctic during the period 1980-2000 compared to the preceding and succeeding periods. This would mean a shorter processing time for the air masses and hence less alkyl nitrate production and lower alkyl nitrate to alkane ratios. This is the opposite to what we observe in the firn records, suggesting that changes to the NAO are unlikely to be responsible for the observed alkyl nitrate trends.

Concerning (ii), changes to the relative distribution of the major source regions of the alkanes could have occurred for a number of reasons. Fuel composition has changed through time as a response to technological development of vehicles. Clean air legislation has led to the development of cars with progressively lower evaporative and tailpipe emissions (e.g. Wallington et al., 2006), through developments such as catalytic converters. In addition emissions may have changed simply due to a change in vehicle usage. If such changes were to have occurred in more northerly regions significantly earlier than in more southerly regions, this could have increased the mean transport time of air masses to the Arctic.

For many areas in North America, the Reid vapour pressure of fuel is regulated in the summer season (1 June15 September) (epa.gov.uk), leading to sale of a different fuel mix in summer compared to winter. This is generally achieved by producers reducing the butane content of the fuel (Gentner et al., 2006). This legislation was introduced in 1990. However, the observed alkane and alkyl nitrate signals in Greenland are almost entirely wintertime signals (e.g. Swanson et al., 2003), and so such seasonal variation in fuel composition would not be expected to affect the firn measurements.

The main source of anthropogenic emissions to the Arctic of gases with lifetimes of the order of a few weeks, particularly during the winter, has been identified as northern Eurasia (e.g. Shindell et al., 2008; Stohl et al., 2007; Klonecki et al., 2003). Emissions from Europe and North America have followed a similar declining trend in recent years (Lamarque et al., 2010; von Schneidemesser et al., 2010; Warneke et al., 2012); thus the relative contribution from each region is not expected to have changed dramatically.

\subsection{The hydroxyl radical, $\mathrm{OH}$}

The alternative explanation for an increase in photochemical processing is an increase in the mean $[\mathrm{OH}]$ to which the air mass is exposed. This would represent a regional trend in $[\mathrm{OH}]$ that is representative of regions from and through which air masses are transported to the Arctic, and would relate primarily to the winter (since the alkyl nitrate and alkane signals in the firn are dominated by wintertime concentrations). It is noted that the increased chemical processing ob- served could also result from an increase in an oxidant other than $\mathrm{OH}$, e.g. atomic chlorine, as suggested in Helmig et al. (2014b).

Studies using changes to atmospheric mixing ratios of methyl chloroform $\left(\mathrm{CH}_{3} \mathrm{CCl}_{3}\right)$ have suggested that global mean $\mathrm{OH}$ concentrations are "well buffered" (e.g. Montzka et al., 2011). Since the main sink of $\mathrm{CH}_{3} \mathrm{CCl}_{3}$ in the atmosphere is reaction with $\mathrm{OH}$, and the emission sources and other sinks are thought to be well constrained, the variation in its observed mixing ratios at a number of remote sites can be used to infer variations in global $[\mathrm{OH}]$. Global mean $[\mathrm{OH}]$ has been inferred in this way in a number of studies (Prinn et al., 1995, 2001, 2005; Rigby et al., 2008; Montzka et al., 2011). The most recent of these (Montzka et al., 2011) reported little interannual variability in mean global atmospheric $[\mathrm{OH}]$, estimating roughly $5 \%$ variation from the mean value during the period 1997-2008, but this does not cover the period of interest here (1970 to late 1990s). Similarly, Kai et al. (2011) inferred a low variability in global [OH] between 1998 and 2005 based on a relatively constant $\delta$-D- $\mathrm{CH}_{4}$. Earlier work using methyl chloroform (Prinn et al., $2001)$ reported an increase in $\mathrm{NH}[\mathrm{OH}]$ of roughly $40 \%$ between 1979 and 1991 but this increase has been questioned in more recent work (e.g. Montzka et al., 2011).

However, there are a growing number of observational data sets of trace gases in the $\mathrm{NH}$ which show trends since 1980 that could be explained, at least in part, by changes to the concentration of the $\mathrm{OH}$ sink. E.g. decreasing Arctic alkane mixing ratios (Helmig et al., 2014b; Aydin et al., 2011), decreasing Arctic CO mixing ratios (Petrenko et al., 2013), increasing $d^{13} \mathrm{C}$ of methane (Monteil et al., 2011; Sapart et al., 2013), and decreasing $d \mathrm{C}^{16} \mathrm{O}$ of Arctic CO (Wang et al., 2012).

A recent multi-model intercomparison exercise of seventeen global chemical transport models, showed agreement for a small increasing trend in global mean $[\mathrm{OH}]$ of $3.5( \pm 2.2) \%$ between 1980 and 2000 and a slightly larger $[\mathrm{OH}]$ increase in the Northern Hemisphere of $4.6( \pm 1.9) \%$ (Naik et al., 2013). Dalsøren et al. (2016) determined an increase in global mean [OH] of about $10 \%$ between 1970 and 2006 from modelled increases of the methane lifetime.

\section{Discussion}

The alkyl nitrate trends presented herein suggest a profound change to the chemical state of the Northern Hemisphere mid-high latitude atmosphere in winter between the 1970s and the late 1990s and then again between the late 1990s and the mid-2000s.

A key species of the tropospheric chemistry cycle, tightly linked to $\mathrm{NO}_{x}$ and $\mathrm{HO}_{x}$, is ozone (Fig. 1). Ozone mixing ratios increased at background sites across the $\mathrm{NH}$ during the second half of the twentieth century, roughly doubling since 1960 (Parrish et al., 2012). Ozone production is positively 
linked to $\left[\mathrm{NO}_{x}\right]$ (at low $\mathrm{NO}_{x}$ concentrations such as the background atmosphere). Hence, an increase in the $[\mathrm{NO}] /\left[\mathrm{HO}_{2}\right]$ ratio from around 1970 to the mid-1990s is consistent with long-term trends in ozone in the background atmosphere.

Furthermore, while the alkyl nitrate measurements represent changes to the wintertime atmosphere, the ozone trends are seen in both summer and winter. If these are being driven by increases to $\left[\mathrm{NO}_{x}\right]$ in the background atmosphere, then this suggests that the chemical changes to the atmosphere may have been present throughout the year and are not just a wintertime phenomenon.

This work also implies that there may have been a change in $[\mathrm{OH}]$. Indeed due to the connected nature of the chemistry of $\mathrm{NO}_{x}$, ozone and $\mathrm{OH}$ (Fig. 1) it seems unlikely, given the implied increases in $\mathrm{NO}_{x}$ suggested here and the recorded increases in ozone (Parrish et al., 2012), that there was not a commensurate increase in $\mathrm{OH}$ production during this period. A major primary production route of $\mathrm{OH}$ is via photolysis of ozone (Eq. 8 - Smith et al., 2006).

$$
P(\mathrm{OH})=2 f\left[\mathrm{O}_{3}\right] \times j\left(\mathrm{O}^{1} \mathrm{D}\right),
$$

where $P(\mathrm{OH})$ is primary production of $\mathrm{OH}$, and $f$ is the fraction of $\mathrm{O}\left({ }^{1} \mathrm{D}\right)$ that reacts with water vapour. Ozone has increased at background sites between 1960 and 2000 (Parrish et al., 2012) and measured water vapour has also increased slightly (Hartmann et al., 2013). It therefore seems that the primary production of $\mathrm{OH}$ in the background atmosphere from this source must have increased through the final decades of the past century. Another primary $\mathrm{OH}$ source is via ozonolysis of alkenes (Johnson and Marston, 2008). A third source of $\mathrm{OH}$ that may be important is photolysis of HONO (e.g. Stone et al., 2012). There is still considerable uncertainty about the sources of HONO, with formation from heterogeneous conversion of $\mathrm{NO}_{2}$ via a range of postulated processes appearing to dominate over the $\mathrm{HO}_{x} / \mathrm{NO}_{x}$ recycling reaction $\mathrm{OH}+\mathrm{NO}$ (e.g. Michoud et al., 2014). This again would be a primary source of $\mathrm{OH}$ which would be expected to correlate positively with $\mathrm{NO}_{x}$ concentrations.

The primary sink of $\mathrm{OH}$ in the background atmosphere, CO, has decreased by about $15 \%$ since 1980 (Petrenko et al., 2013), with the secondary sink, $\mathrm{CH}_{4}$, having increased between 1980 and 2000 by about $15 \%$.

The global growth rate of methane in the atmosphere continually declined throughout the period of the 1970s to 2000, culminating in the "methane pause" between 1999 and 2006 (Dlugockencky et al., 2009). A possible cause of this change in the growth rate of methane could be an increase in $\mathrm{OH}$ concentration (e.g. Dalsøren et al., 2016). This is consistent with an increase in $[\mathrm{OH}]$ also being the cause of the trend in the ratio of alkyl nitrate to parent alkane seen in this work. It should be noted, though, that the majority of the $\mathrm{OH}$ oxidation of methane occurs in the tropics (e.g. Bloss et al., 2005), while any increase in $\mathrm{OH}$ suggested by the work herein must be viewed as representative only of the mid-high latitude
Northern Hemisphere and the wintertime. However, the processes suggested herein, such as changes to the $\mathrm{N}_{2} \mathrm{O}_{5}$ sink, have been shown to be effective at a hemispheric scale.

In a recent intermodel comparison project, ACCMIP, it was shown that models failed to capture the measured magnitude of the increase in ozone over recent decades (Parrish et al., 2014), in particular the steep increase seen between 1980 and 2000. This failure to capture measured changes to ozone may suggest that models are likely to underestimate changes to $\mathrm{OH}$ production, from ozone photolysis or reactions of ozone with alkenes, over the same period (i.e. they may be larger than the $4.6( \pm 1.9) \%$ reported in Naik et al., 2013 for the NH).

Including alkyl nitrate chemistry and using the alkyl nitrate measurements presented herein could provide a valuable constraint for global chemical transport models modelling changes to $\mathrm{NO}_{x}$ and $\mathrm{HO}_{x}$ back to the middle of the twentieth century.

\section{Conclusions}

Time series such as those presented here are fundamental to improving our understanding of trends in atmospheric composition during the twentieth century. The long-term trends of alkyl nitrates presented herein suggest major changes to the chemical state of the atmosphere during the past five decades. The observed large increase in the $\left[\mathrm{RONO}_{2}\right] /[\mathrm{RH}]$ ratio between the 1970s and late 1990s could be explained by a 2-4 fold increase in the mean production efficiency of the alkyl nitrates, driven by an increase in the $[\mathrm{NO}] /\left[\mathrm{HO}_{2}\right]$ ratio in the background atmosphere. This is not consistent with reported changes to Northern Hemisphere $\mathrm{NO}_{x}$ emissions, but may have been driven by a reduction in the $\mathrm{NO}_{x}$ sink. The recent decreases (since the late 1990s) in alkyl nitrate concentrations are in qualitative agreement with recent decreases in $\mathrm{NO}_{x}$ emissions and in measured $\mathrm{NO}_{x}$ concentrations. Alternatively, the observed increase in the $\left[\mathrm{RONO}_{2}\right] /[\mathrm{RH}]$ ratio between the 1970s and late 1990s could be explained by an increase in the amount of photochemical processing $[\mathrm{OH}] t$ of air masses reaching the Arctic by a factor of 2-3. This could be driven by an increase in concentrations of the hydroxyl radical $(\mathrm{OH})$, or to the transport time $(t)$ of air masses from source regions to the Arctic. If the observed trends are driven by changes to the chemical state of the atmosphere, then it is likely that they represent a combination of changes to the concentrations of both $\mathrm{NO}$ and $\mathrm{OH}$.

Data availability. The firn measurements and the firn model output are available as part of the Supplement as an Excel spreadsheet.

The Supplement related to this article is available online at https://doi.org/10.5194/acp-17-8269-2017-supplement. 
Competing interests. The authors declare that they have no conflict of interest.

Acknowledgements. This work was supported by funding from the UK Natural Environment Research Council (NE/F021194/1 \& NE/M003248/1). NEEM is directed and organized by the Centre of Ice and Climate at the Niels Bohr Institute and US NSF, Office of Polar Programs. It is supported by funding agencies and institutions in Belgium (FNRS-CFB and FWO), Canada (NRCan/GSC), China (CAS), Denmark (FIST), France (IPEV, CNRS/INSU, CEA and ANR), Germany (AWI), Iceland (RannIs), Japan (NIPR), South Korea (KOPRI), the Netherlands (NWO/ALW), Sweden (VR), Switzerland (SNF), the United Kingdom (NERC) and the USA (USNSF, Office of Polar Programs) and the EU Seventh Framework programs. We are indebted to Jakob Schwander of the Physics Institute at the University of Bern, Switzerland for collecting the firn air samples at NEEM, and Thomas Blunier of the Centre for Ice and Climate at University of Copenhagen, Denmark for leading the NEEM gas consortium. We thank Chelsea Thompson for useful discussions.

Edited by: Robert McLaren

Reviewed by: two anonymous referees

\section{References}

Aydin, M., Verhulst, K. R., Saltzman, E. S., Battle, M. O., Montzka, S. A., Blake, D. R., Tang, Q., and Prather, M. J.: Recent decreases in fossil-fuel emissions of ethane and methane derived from firn air, Nature, 476, 198-201, https://doi.org/10.1038/nature10352, 2011.

Baker, A. K., Slemr, F., and Brenninkmeijer, C. A. M.: Analysis of non-methane hydrocarbons in air samples collected aboard the CARIBIC passenger aircraft, Atmos. Meas. Tech., 3, 311-321, https://doi.org/10.5194/amt-3-311-2010, 2010.

Battle, M., Bender, M., Sowers, T., Tans, P. P., Butler, J. H., Elkins, J. W., Ellis, J. T., Conway, T., Zhang, N., Lang, P., and Clarke, A. D.: Atmospheric gas concentrations over the past century measured in air from firn at the South Pole, Nature, 383, 231-235, 1996.

Berglen, T. F., Myhre, G., Isaksen, I. S. A., Vestreng, V., and Smith, S. J.: Sulphate trends in Europe: Are we able to model the recent observed decrease?, Tellus B, 59, 773-786, 2007.

Bertman, S. B., Roberts, J. M., Parrish, D. D., Buhr, M. P., Goldan, M. P., Kuster, W. C., Fehsenfeld, F. C., Montzka, S. A., and Westberg, H.: Evolution of alkyl nitrates with air mass age, J. Geophys. Res., 100, 22805-22813, 1995.

Bloss, W. J., Evans, M. J., Lee, J. D., Sommariva, R., Heard, D. E., and Pilling, M. J.: The oxidative capacity of the troposphere: Coupling of field measurements of $\mathrm{OH}$ and a global chemistry transport model, Faraday Discuss., 130, 425-436, 2005.

Brown, S. S. and Stutz, J.: Nighttime radical observations and chemistry, Chem. Soc. Rev. 41, 6405-6447, 2012.

Buizert, C., Martinerie, P., Petrenko, V. V., Severinghaus, J. P., Trudinger, C. M., Witrant, E., Rosen, J. L., Orsi, A. J., Rubino, M., Etheridge, D. M., Steele, L. P., Hogan, C., Laube, J. C., Sturges, W. T., Levchenko, V. A., Smith, A. M., Levin, I.,
Conway, T. J., Dlugokencky, E. J., Lang, P. M., Kawamura, K., Jenk, T. M., White, J. W. C., Sowers, T., Schwander, J., and Blunier, T.: Gas transport in firn: multiple-tracer characterisation and model intercomparison for NEEM, Northern Greenland, Atmos. Chem. Phys., 12, 4259-4277, https://doi.org/10.5194/acp12-4259-2012, 2012.

Carslaw, D. C., Beevers, S. D., Westmoreland, E., Williams, M. L., Tate, J. E., Murrells, T., Stedman, J., Li, Y., Grice, S., Kent, A., and Tsagatakis, I.: Trends in $\mathrm{NO}_{x}$ and $\mathrm{NO}_{2}$ emissions and ambient measurements in the UK, Version: July 2011.

Chen, N. H. and Othmer, D. F.: New generalized equation for gas diffusion coefficient, J. Chem. Eng. Data, 7, 37-41, 1962.

Clemitshaw, K. C., Williams, J., Rattigan, O. V., Shallcross, D. E., Law, K. S., and Cox, R. A.: Gas phase ultraviolet absorption cross sections and atmospheric lifetimes of several C2-C5 alkyl nitrates, J. Photochem. Photobiol. A, 102, 117-126, 1997.

Dalsøren, S. B., Myhre, C. L., Myhre, G., Gomez-Pelaez, A. J., Søvde, O. A., Isaksen, I. S. A., Weiss, R. F., and Harth, C. M.: Atmospheric methane evolution the last 40 years, Atmos. Chem. Phys., 16, 3099-3126, https://doi.org/10.5194/acp16-3099-2016, 2016.

Dentener, F. J. and Crutzen, P.: Reaction of $\mathrm{N}_{2} \mathrm{O}_{5}$ on Tropospheric Aerosols: Impact on the Global Distributions of $\mathrm{NO}_{x}, \mathrm{O}_{3}$, and OH, J. Geophys. Res., 98, 7149-7163, 1993.

Derwent, R. G., Simmonds, P. G., O’Doherty, S., Grant, A., Young, D., Cooke, M. C., Manning, A. J., Utembe, S. R., Jenkin, M. E., and Shallcross, D. E.: Seasonal cycles in short-lived hydrocarbons in baseline air masses arriving at Mace Head, Ireland, Atmos. Environ., 62, 89-96, 2012.

Dibb, J. E., Albert, M., Courville, Z., Anastasio, C., Galbavy, E. S., Atlas, E., Beyersdorf, A. J., Blake, D. R., Meinardi, S., Sherwood Rowland, F., Swanson, A. L., Blake, N. J., Bocquet, F., Cohen, L., Helmig, D., Burkhart, J. F., Frey, M. M., Friel, D. K., Hutterli, M. A., Chen, G., Conway, T. J., and Oltmans, S. J.: An overview of air-snow exchange at Summit, Greenland: Recent experiments and findings, Atmos. Environ., 41, 4995-5006, 2007.

Dlugokencky, E. J., Bruhwiler, L., White, J. W. C., Emmons, L. K., Novelli, P. C., Montzka, S. A., Masarie, K. A., Lang, P. M., Crotwell, A. M., Miller, J. B., and Gatti, L. V.: Observational constraints on recent increases in the atmospheric $\mathrm{CH}_{4}$ burden, Geophys. Res. Lett., 36, L18803, https://doi.org/10.1029/2009GL039780, 2009.

Dollard, G. J., Dumitrean, P., Telling, S., Dixon, J., and Derwent, R. G.: Observed trends in ambient concentrations of C2-C8 hydrocarbons in the United Kingdom over the period from 1993 to 2004, Atmos. Environ., 41, 2559-2569, 2007.

EC-JRC/PBL (European Commission, Joint Research Centre/ Netherlands Environmental Assessment Agency): Emission Database for Global Atmospheric Research (EDGAR), release version 4.2: available at: http://edgar.jrc.ec.europa.eu (last access: April 2017), 2011.

Eckhardt, S., Stohl, A., Beirle, S., Spichtinger, N., James, P., Forster, C., Junker, C., Wagner, T., Platt, U., and Jennings, S. G.: The North Atlantic Oscillation controls air pollution transport to the Arctic, Atmos. Chem. Phys., 3, 1769-1778, https://doi.org/10.5194/acp-3-1769-2003, 2003.

Fuller, E. N., Schettler, P. D., and Giddings, J. C.: A new method for prediction of binary gas-phase diffusion coefficients, Ind. Eng. Chem., 58, 19-27, 1966. 
Gentner, D. R., Harley, R. A., Miller, A. M., and Goldstein, A. H.: Diurnal and Seasonal Variability of Gasoline-Related Volatile Organic Compound Emissions in Riverside, California, Environ. Sci. Technol., 43, 4247-4252, 2009.

Gilge, S., Plass-Duelmer, C., Fricke, W., Kaiser, A., Ries, L., Buchmann, B., and Steinbacher, M.: Ozone, carbon monoxide and nitrogen oxides time series at four alpine GAW mountain stations in central Europe, Atmos. Chem. Phys., 10, 12295-12316, https://doi.org/10.5194/acp-10-12295-2010, 2010.

Hartmann, D. L., Klein Tank, A. M. G., Rusticucci, M., Alexander, L. V., Brönnimann, S., Charabi, Y., Dentener, F. J., Dlugokencky, E. J., Easterling, D. R., Kaplan, A., Soden, B. J., Thorne, P. W., Wild, M., and Zhai, P. M.: Observations: Atmosphere and Surface. in: Climate Change 2013: The Physical Science Basis. Contribution of Working Group I to the Fifth Assessment Report of the Intergovernmental Panel on Climate Change, edited by: Stocker, T. F., Qin, D., Plattner, G.-K., Tignor, M., Allen, S. K., Boschung, J., Nauels, A., Xia, Y., Bex, V., and Midgley, P. M., Cambridge University Press, Cambridge, United Kingdom and New York, NY, USA, 2013

Heard, D., Carpenter, L. J., Creasey, D. J., Hopkins, J. R., Lee, J. D., Lewis, A. C., Pilling, M. J., Seakins, P. W., Carslaw, N., and Emmerson, K. M.: High levels of the hydroxyl radical in the winter urban troposphere, Geophys. Res. Lett., 31, L18112, https://doi.org/10.1029/2004GL020544, 2004.

Helmig, D., Bottenheim, J., Galbally, I. E., Lewis, A., Milton, M. J. T., Penkett, S., Plass-Duelmer, C., Reimann, S., Tans, P., and Thiel, S.: Volatile Organic Compounds in the Global Atmosphere, Eos Trans., AGU, 90, Feature, 2009.

Helmig, D., Thompson, C. R., Evans, J., Boylan, P., Hueber, J., and Park, J.-H.: Highly elevated atmospheric levels of volatile organic compounds in the Uintah basin, Utah, Environ. Sci. Technol., 48, 4707-4715, 2014a.

Helmig, D., Petrenko, V., Martinerie, P., Witrant, E., Röckmann, T., Zuiderweg, A., Holzinger, R., Hueber, J., Thompson, C., White, J. W. C., Sturges, W., Baker, A., Blunier, T., Etheridge, D., Rubino, M., and Tans, P.: Reconstruction of Northern Hemisphere 1950-2010 atmospheric non-methane hydrocarbons, Atmos. Chem. Phys., 14, 1463-1483, https://doi.org/10.5194/acp14-1463-2014, 2014b.

Hirdman, D., Burkhart, J. F., Sodemann, H., Eckhardt, S., Jefferson, A., Quinn, P. K., Sharma, S., Ström, J., and Stohl, A.: Long-term trends of black carbon and sulphate aerosol in the Arctic: changes in atmospheric transport and source region emissions, Atmos. Chem. Phys., 10, 9351-9368, https://doi.org/10.5194/acp-109351-2010, 2010.

Hurrell, J. W. and Deser, C.: North Atlantic climate variability: The role of the North Atlantic Oscillation, J. Marine Syst., 79, 231244,2010

Jenkin, M. E., Saunders, S. M., and Pilling, M. J.: The tropospheric degradation of volatile organic compounds: a protocol for mechanism development, Atmos. Environ., 31, 81-104, 1997.

Johnson, D. and Marston, G.: The gas-phase ozonolysis of unsaturated volatile organic compounds in the troposphere, Chem. Soc. Rev., 37, 699-716, 2008.

Kahl, J. D. W., Galbraith, J. A., and Martinez, D. A.: Decadal-scale variability in long range atmospheric transport to the Summit of the Greenland Ice Sheet, Geophys. Res. Lett., 26, 481-484, 1999.
Kai, F. M., Tyler, S. C., Randerson, J. T, and Blake, D. R.: Reduced methane growth rate explained by decreased Northern Hemisphere microbial sources, Nature, 476, 194-197, 2011.

Klonecki, A., Hess, P., Emmons, L., Smith, L., Orlando, J., and Blake, D.: Seasonal changes in the transport of pollutants into the Arctic troposphere - model study, J. Geophys. Res., 108, 8367, https://doi.org/10.1029/2002JD002199, 2003.

Lamarque, J.-F., Bond, T. C., Eyring, V., Granier, C., Heil, A., Klimont, Z., Lee, D., Liousse, C., Mieville, A., Owen, B., Schultz, M. G., Shindell, D., Smith, S. J., Stehfest, E., Van Aardenne, J., Cooper, O. R., Kainuma, M., Mahowald, N., McConnell, J. R., Naik, V., Riahi, K., and van Vuuren, D. P.: Historical (1850-2000) gridded anthropogenic and biomass burning emissions of reactive gases and aerosols: methodology and application, Atmos. Chem. Phys., 10, 7017-7039, https://doi.org/10.5194/acp-10-7017-2010, 2010.

Michoud, V., Colomb, A., Borbon, A., Miet, K., Beekmann, M., Camredon, M., Aumont, B., Perrier, S., Zapf, P., Siour, G., AitHelal, W., Afif, C., Kukui, A., Furger, M., Dupont, J. C., Haeffelin, M., and Doussin, J. F.: Study of the unknown HONO daytime source at a European suburban site during the MEGAPOLI summer and winter field campaigns, Atmos. Chem. Phys., 14, 2805-2822, https://doi.org/10.5194/acp-14-2805-2014, 2014.

Monteil, G., Houweling, S., Dlugockenky, E. J., Maenhout, G., Vaughn, B. H., White, J. W. C., and Rockmann, T.: Interpreting methane variations in the past two decades using measurements of $\mathrm{CH}_{4}$ mixing ratio and isotopic composition, Atmos. Chem. Phys., 11, 9141-9153, https://doi.org/10.5194/acp11-9141-2011, 2011.

Montzka, S. A., Krol, M., Dlugockenky, E., Hall, B., Jöckel, P., and Lelieveld, J.: Small Interannual Variability of Global Atmospheric Hydroxyl, Science, 331, 67-69, 2011.

Murphy, J. G., Gregoire, P. K., Tevlin, A. G., Wentworth, G. R., Ellis, R. A., Markovic, M. Z., and Vandenboer, T. C.: Observational constraints on particle acidity using measurements and modelling of particles and gases, Faraday Discuss., https://doi.org/10.1039/c7fd00086c, online first, 2017.

Naik, V., Voulgarakis, A., Fiore, A. M., Horowitz, L. W., Lamarque, J.-F., Lin, M., Prather, M. J., Young, P. J., Bergmann, D., Cameron-Smith, P. J., Cionni, I., Collins, W. J., Dalsøren, S. B., Doherty, R., Eyring, V., Faluvegi, G., Folberth, G. A., Josse, B., Lee, Y. H., MacKenzie, I. A., Nagashima, T., van Noije, T. P. C., Plummer, D. A., Righi, M., Rumbold, S. T., Skeie, R., Shindell, D. T., Stevenson, D. S., Strode, S., Sudo, K., Szopa, S., and Zeng, G.: Preindustrial to present-day changes in tropospheric hydroxyl radical and methane lifetime from the Atmospheric Chemistry and Climate Model Intercomparison Project (ACCMIP), Atmos. Chem. Phys., 13, 5277-5298, https://doi.org/10.5194/acp13-5277-2013, 2013.

Olivier, J. G. J. and Berdowski, J. J. M.: Global emissions sources and sinks, in: The Climate System, edited by: Berdowski, J., Guicherit, R., and Heij, B. J., A.A. Balkema/Swets and Zeitlinger, Lisse, The Netherlands, 33-78, 2001.

Olivier, J. G. J., Berdowski, J. J. M., Peters, J. A. H. W., Bakker, J., Visschedijk, A. J. H., and Bloos, J. P. J.: Applications of EDGAR. Including a Description of EDGAR 3.0: Reference Database with Trend Data for 1970-1995, RIVM, Biltoven, 2001.

Parrish, D. D., Law, K. S., Staehelin, J., Derwent, R., Cooper, O. R., Tanimoto, H., Volz-Thomas, A., Gilge, S., Scheel, 
H.-E., Steinbacher, M., and Chan, E.: Long-term changes in lower tropospheric baseline ozone concentrations at northern mid-latitudes, Atmos. Chem. Phys., 12, 11485-11504, https://doi.org/10.5194/acp-12-11485-2012, 2012.

Parrish, D. D., Lamarque, J, -F., Naik, V., Horowitz, L., Shindell, D. T., Staehelin, J., Derwent, R., Cooper, O. R., Tanimoto, H., Volz-Thomas, A., Gilge, S., Scheel, H.-E., Steinbacher, M., and Froehlich, M.: Long-term changes in lower tropospheric baseline ozone concentrations: Comparing chemistry-climate models and observations at northern mid-latitudes, J. Geophys. Res.-Atmos., 119, https://doi.org/10.1002/2013JD021435, 2014.

Petrenko, V. V., Martinerie, P., Novelli, P., Etheridge, D. M., Levin, I., Wang, Z., Blunier, T., Chappellaz, J., Kaiser, J., Lang, P., Steele, L. P., Hammer, S., Mak, J., Langenfelds, R. L., Schwander, J., Severinghaus, J. P., Witrant, E., Petron, G., Battle, M. O., Forster, G., Sturges, W. T., Lamarque, J.-F., Steffen, K., and White, J. W. C.: A $60 \mathrm{yr}$ record of atmospheric carbon monoxide reconstructed from Greenland firn air, Atmos. Chem. Phys., 13, 7567-7585, https://doi.org/10.5194/acp-13-7567-2013, 2013.

Pétron, G., Frost, G., Miller, B. R., Hirsch, A. I., Montzka, S. A., Karion, A., Trainer, M., Sweeney, C., Andrews, A. E., Miller, L., Kofler, J., Bar-Ilan, A., Dlugokencky, E. J., Patrick, L., Moore, C. T., Ryerson, T. B., Siso, C., Kolodzey, W., Lang, P. M., Conway, T., Novelli, P., Masarie, K., Hall, B., Guenther, D., Kitzis, D., Miller, J., Welsh, D., Wolfe, D., Neff, W., and Tans, P.: Hydrocarbon emissions characterization in the Colorado Front Range: A pilot study, J. Geophys. Res.-Atmos., 117, D04304, https://doi.org/10.1029/2011JD016360, 2012.

Pollmann, J., Helmig, D., Hueber, J., Plass-Duelmer, C., and Tans, P.: Sampling, storage, and analysis of C2-C7 non-methane hydrocarbons from the US National Oceanic and Atmospheric Administration Cooperative Air Sampling Network glass flasks, J. Chromatogr. A, 1188, 75-87, 2008.

Pozzer, A., Pollmann, J., Taraborrelli, D., Jöckel, P., Helmig, D., Tans, P., Hueber, J., and Lelieveld, J.: Observed and simulated global distribution and budget of atmospheric C2-C5 alkanes, Atmos. Chem. Phys., 10, 4403-4422, https://doi.org/10.5194/acp10-4403-2010, 2010.

Prinn, R. G., Weiss, R. F., Miller, B. R., Huang, J., Aleya, F. N., Cunnold, D. M., Fraser, P. J., Hartley, D. E., and Simmonds, P. G.: Atmospheric trends and lifetime of $\mathrm{CH}_{3} \mathrm{CCl}_{3}$ and global $\mathrm{OH}$ concentrations, Science, 269, 187-192, 1995.

Prinn, R. G., Huang, J., Weiss, R. F., Cunnold, D. M., Fraser, P. J., Simmonds, P. G., McCulloch, A., Harth, C. M., Salameh, P. K., O'Doherty, S., Wang, R. H. J., Porter, L., and Miller, B. R.: Evidence for substantial variations of atmospheric hydroxyl radicals in the past two decades, Science, 292, 1882-1888, 2001.

Prinn, R. G., Huang, J., Weiss, R. F., Cunnold, D. M., Fraser, P. J., Simmonds, P. G., McCulloch, A., Harth, C. M., Reimann, S., Salameh, P. K., O’Doherty, S., Wang, R. H. J., Porter, L. W., Miller, B. R., and Krummel P. B.: Evidence for variability of atmospheric hydroxyl radicals over the past quarter century, Geophys. Res. Lett., 32, L07809, https://doi.org/10.1029/2004GL022228, 2005.

Rigby, M., Prinn, R. G., Fraser, P. J., Simmonds, P. G., Langenfelds, R. L., Huang, J., Cunnold, D. M., Steele, L. P., Krummel, P. B., Weiss, R. F., O'Doherty, S., Salameh, P. K., Wang, H. J., Harth, C. M., Mühle, J., and Porter, L. W.: Re- newed growth of atmospheric methane, Geophys. Res. Lett., 35, L22805, https://doi.org/10.1029/2008GL036037, 2008.

Sapart, C. J., Martinerie, P., Witrant, E., Chappellaz, J., van de Wal, R. S. W., Sperlich, P., van der Veen, C., Bernard, S., Sturges, W. T., Blunier, T., Schwander, J., Etheridge, D., and Röckmann, T.: Can the carbon isotopic composition of methane be reconstructed from multi-site firn air measurements?, Atmos. Chem. Phys., 13, 6993-7005, https://doi.org/10.5194/acp-13-6993-2013, 2013.

Schwander, J., Barnola, J.-M., Andrié, C., Leuenberger, M., Ludin, A., Raynaud, D., and Stauffer, B.: The age of the air in the firn and the ice at Summit, Greenland, J. Geophys. Res., 98, 28312838, 1993.

Shindell, D. T., Chin, M., Dentener, F., Doherty, R. M., Faluvegi, G., Fiore, A. M., Hess, P., Koch, D. M., MacKenzie, I. A., Sanderson, M. G., Schultz, M. G., Schulz, M., Stevenson, D. S., Teich, H., Textor, C., Wild, O., Bergmann, D. J., Bey, I., Bian, H., Cuvelier, C., Duncan, B. N., Folberth, G., Horowitz, L. W., Jonson, J., Kaminski, J. W., Marmer, E., Park, R., Pringle, K. J., Schroeder, S., Szopa, S., Takemura, T., Zeng, G., Keating, T. J., and Zuber, A.: A multi-model assessment of pollution transport to the Arctic, Atmos. Chem. Phys., 8, 5353-5372, https://doi.org/10.5194/acp-8-5353-2008, 2008.

Smith, S. C., Lee, J. D., Bloss, W. J., Johnson, G. P., Ingham, T., and Heard, D. E.: Concentrations of $\mathrm{OH}$ and $\mathrm{HO}_{2}$ radicals during NAMBLEX: measurements and steady state analysis, Atmos. Chem. Phys., 6, 1435-1453, https://doi.org/10.5194/acp-6-14352006, 2006.

Smith, S. J., van Aardenne, J., Klimont, Z., Andres, R. J., Volke, A., and Delgado Arias, S.: Anthropogenic sulfur dioxide emissions: 1850-2005, Atmos. Chem. Phys., 11, 1101-1116, https://doi.org/10.5194/acp-11-1101-2011, 2011.

Stevenson, D. S., Johnson, C. E., Collins, W. J., and Derwent, R. G.: The tropospheric sulphur cycle and the role of volcanic $\mathrm{SO}_{2}$, in Volcanic Degassing edited by Oppenheimer, C., Pyle, D. M., and Barclay, J., Geol. Soc. Lond. Spec. Pub., 213, 295-305, 2003.

Stohl, A.: Characteristics of atmospheric transport into the Arctic troposphere, J. Geophys. Res.-Atmos., 111, D11306, https://doi.org/10.1029/2005JD006888, 2006.

Stohl, A., Berg, T., Burkhart, J. F., Fjǽraa, A. M., Forster, C., Herber, A., Hov, Ø., Lunder, C., McMillan, W. W., Oltmans, S., Shiobara, M., Simpson, D., Solberg, S., Stebel, K., Ström, J., Tørseth, K., Treffeisen, R., Virkkunen, K., and Yttri, K. E.: Arctic smoke - record high air pollution levels in the European Arctic due to agricultural fires in Eastern Europe in spring 2006, Atmos. Chem. Phys., 7, 511-534, https://doi.org/10.5194/acp-7511-2007, 2007.

Stone, D., Whalley, L. K., and Heard, D. E.: Tropospheric OH and $\mathrm{HO}_{2}$ radicals: field measurements and model comparisons, Chem. Soc. Rev., 41, 6348-6404, 2012.

Swanson, A., Blake, N., Atlas, E., Flocke, F., Blake, D. R., and Sherwood, F.: Seasonal variation of $\mathrm{C} 2-\mathrm{C} 4$ nonmethane hydrocarbons and $\mathrm{C} 1-\mathrm{C} 4$ alkyl nitrates at the Summit research station in Greenland, J. Geophys. Res., 108, ACH 7-1-ACH 7-19, 2003.

Talukdar, R. K., Herndon, S. C., Burkholder, J. B., Roberts, J. M., and Ravishankara, A. R.: Atmospheric fate of several alkyl nitrates. 1. Rate coefficients of the reactions alkyl nitrates with isotopically labelled hydroxyl radicals, J. Chem. Soc. Faraday T., 93, 2787-2796, 1997. 
Tuazon, E. C., Atkinson, R., Plum, N. C., Winer, A. M., and Pitts, J. $\mathrm{N}$.: The reaction of gas-phase $\mathrm{N}_{2} \mathrm{O}_{5}$ with water vapour, Geophys. Res. Lett., 10, 953-956, 1983.

Turnock, S. T., Spracklen, D. V., Carslaw, K. S., Mann, G. W., Woodhouse, M. T., Forster, P. M., Haywood, J., Johnson, C. E., Dalvi, M., Bellouin, N., and Sanchez-Lorenzo, A.: Modelled and observed changes in aerosols and surface solar radiation over Europe between 1960 and 2009, Atmos. Chem. Phys., 15, 94779500, https://doi.org/10.5194/acp-15-9477-2015, 2015.

Vestreng, V., Ntziachristos, L., Semb, A., Reis, S., Isaksen, I. S. A., and Tarrasón, L.: Evolution of $\mathrm{NO}_{x}$ emissions in Europe with focus on road transport control measures, Atmos. Chem. Phys., 9, 1503-1520, https://doi.org/10.5194/acp-9-1503-2009, 2009.

von Schneidemesser, E., Monks, P. S., and Plass-Duelmer, C.: Global comparison of VOC and CO observations in urban areas, Atmos. Environ., 44, 5053-5064, 2010.

Wallington, T. J., Kaiser, E. W., and Farrell, J. T.: Automotive fuels and internal combustion engines: A chemical perspective, Chem. Soc. Rev., 35, 335-347, 2006.

Wang, Z., Chappellaz, J., Martinerie, P., Park, K., Petrenko, V., Witrant, E., Emmons, L. K., Blunier, T., Brenninkmeijer, C. A. M., and Mak, J. E.: The isotopic record of Northern Hemisphere atmospheric carbon monoxide since 1950: implications for the CO budget, Atmos. Chem. Phys., 12, 4365-4377, https://doi.org/10.5194/acp-12-4365-2012, 2012.

Warneke, C., De Gouw., J. A., Holloway, J., S., Peischl, J., Ryerson, T. B., Atlas, E., Blake, D., Trainer, M., and Parrish, D. D.: Multiyear trends in volatile organic compounds in Los Angeles, California: Five decades of decreasing emissions, J. Geophys. Res., 117, D00V17, https://doi.org/10.1029/2012JD017899, 2012.
Wild, M., Gilgen, H., Roesch, A., Ohmura, A., Long, C. N., Dutton, E. G., Forgan, B., Kallis, A., Russak, V., and Tsvetkov, A.: From dimming to brightening: decadal changes in solar radiation at earth's surface, Science, 308, 847-850, 2005.

Witrant, E., Martinerie, P., Hogan, C., Laube, J. C., Kawamura, K., Capron, E., Montzka, S. A., Dlugokencky, E. J., Etheridge, D., Blunier, T., and Sturges, W. T.: A new multi-gas constrained model of trace gas non-homogeneous transport in firn: evaluation and behaviour at eleven polar sites, Atmos. Chem. Phys., 12, 11465-11483, https://doi.org/10.5194/acp-12-114652012, 2012.

Witrant, E. and Martinerie, P.: Input Estimation from Sparse Measurements in LPV Systems and Isotopic Ratios in Polar Firns, Proc. of the 5th IFAC Symposium on System Structure and Control, Grenoble, France, 4-6 February 2013.

Worton, D. R., Mills, G. P., Oram, D. E., and Sturges, W. T.: Gas chromatography negative ion chemical ionization mass spectrometry: application to the detection of alkyl nitrates and halocarbons in the atmosphere, J. Chromatogr. A, 1201, 112-119, 2008.

Worton, D. W., Sturges, W. T., Reeves, C. E., Newland, M. J., Penkett, S. A., Atlas, E., Stroud, V., Johnson, K., Schmidbauer, N., Solberg, S., Schwander, J., and Barnola, J.-M.: Evidence from firn air for recent decreases in non-methane hydrocarbons and a 20th century increase in nitrogen dioxides in the northern hemisphere, Atmos. Environ., 54, 592-602, 2012. 